\title{
Seasonal extrema of sea surface temperature in CMIP6 models
}

\author{
Yanxin Wang $^{1}$, Karen J. Heywood ${ }^{1}$, David P. Stevens ${ }^{1}$, and Gillian M. Damerell ${ }^{1}$ \\ ${ }^{1}$ Centre for Ocean and Atmospheric Sciences, University of East Anglia, Norwich, UK
}

Correspondence: Yanxin Wang (Yanxin.Wang@uea.ac.uk)

\begin{abstract}
CMIP6 model sea surface temperature (SST) seasonal extrema averaged over 1981-2010 are assessed against the World Ocean Atlas (WOA18) observational climatology. We propose a mask to identify and exclude regions of large differences between three commonly-used climatologies. The biases in SST seasonal extrema are largely consistent with the annual mean SST biases. However, the amplitude and spatial pattern of SST bias vary seasonally in the 20 CMIP6 models assessed. Large seasonal variations in the SST bias occur in eastern boundary upwelling regions, polar regions, the North Pacific and eastern equatorial Atlantic. These results demonstrate the importance of evaluating model performance not simply against annual mean properties. Models with greater vertical resolution in their ocean component typically demonstrate better representation of SST extrema, particularly seasonal maximum SST. No significant relationship with horizontal ocean model resolution is found.
\end{abstract}

\section{Introduction}

Seasonal extrema of sea surface temperature (SST) are important for the global climate system. SST seasonal maxima influence the formation and intensity of tropical cyclones (Palmen, 1948; Dare and McBride, 2011; Holland, 1997; Sun et al., 2017) and may be associated with marine heatwaves, which can cause damage to marine ecosystems worldwide, including biomass decrease, bleaching of coral reefs, and deaths of marine animals (Cheung and Frölicher, 2020; Hughes et al., 2018; Jones et al., 2018). SST seasonal minima are closely linked to formation of sea ice and determine the properties of intermediate and deep water. Heat loss in winter allows surface water to subduct into the deep ocean, important for thermohaline circulation. Therefore, future projections of tropical cyclones, heatwaves, water mass formation or sea ice extent require our models to have a realistic representation of SST seasonal extrema.

Typically, however, evaluations of climate model historical runs focus on annual or long-term mean SST, revealing common biases across many models (Wang et al., 2014; Flato et al., 2013). Assessments of model performance in simulating SST seasonal cycles are less common, and are often only regional. For example, a marked seasonal variability of SST warm bias in the eastern tropical Atlantic has been documented in CMIP5 (Coupled Model Intercomparison Project Phase 5) and CMIP6 (CMIP Phase 6) models (Prodhomme et al., 2019; Richter et al., 2014; Richter and Tokinaga, 2020). In these models, the eastern tropical Atlantic warm bias is maximum in boreal summer (June-July-August), which has been attributed to the largest wind biases occurring during spring (Richter et al., 2012; Richter and Tokinaga, 2020). Similarly, CMIP6 model SST cold biases in the North Pacific subtropics vary seasonally (Zhu et al., 2020). Song and Zhang (2020) suggested that the CMIP5 multi-model mean has seasonally dependent SST biases in the northeastern Pacific Ocean, with a warm bias during summer 
https://doi.org/10.5194/os-2021-102

Preprint. Discussion started: 27 October 2021

and a cold bias during winter, which they argued was caused by poorly simulated North American monsoon winds. Wang et al. (2014) showed that the amplitude of CMIP5 multi-model mean SST biases varies seasonally and therefore an accurate annual mean SST does not guarantee accurate seasonal extrema or seasonal cycle. Here we evaluate the seasonal cycle globally in 20 state-of-the-art CMIP6 climate models, to provide a foundation for model SST bias identification and future reduction. By presenting maps of SST bias in seasonal extrema for each model, we highlight the care needed in selecting these models for future climate projections in particular regions. Section 2 introduces the models and the analysis techniques, including evaluation of uncertainties in global observational climatologies. Section 3 presents and discusses the biases in SST maxima and minima, and explores possible causes.

\section{Data and Methods}

The historical runs of 20 models (table 1) were averaged over 1981-2010 to create monthly mean climatologies for each model. The first ensemble member (r1i1p1f1) is used where available; we choose r1i1p1f3 for HadGEM3-GC3-LL and HadGEM3GC3-MM; r1i1p1f2 for UKESM1-0-LL. The models include those incorporating biogeochemical cycling (earth system models) as well as conventional climate models. The ocean vertical coordinate is typically z-level (or the related $z^{*}$ ) but some models use isopycnal, sigma or hybrid coordinates (table 1). The total number of levels and thickness of top grid cell are used as proxies for ocean vertical resolution. The global averaged thickness of top grid cell in INM-CM5-0 was calculated using the sigma coordinates and bottom topography obtained from E.M.Volodin (personal communication). The thickness of the top grid cell in other models was obtained from the references cited in table 1.

To examine the seasonal cycle of SST, most studies picked specific months to represent summer and winter (e.g., Zhang and Zhao (2015); Liu et al. (2020)). However, model seasonal cycles may be out of phase with observations and observed maxima and minima occur in different months in different regions. Instead, here we take the maximum and minimum SST of the monthly mean climatologies $\left(T_{\max }\right.$ and $T_{\text {min }}$ ) at each grid point, identifying which months they occur in, for both model and observation. $T_{\max }$ and $T_{\min }$, plus the annual mean SST $\left(T_{\text {mean }}\right)$ and the range of the seasonal cycle $\left(T_{c y c l e}=T_{\max }-T_{\min }\right)$ from the model climatologies are compared with the World Ocean Atlas 2018 (WOA18) observational climatology on a grid spacing of $0.25^{\circ} \times 0.25^{\circ}$ (Locarnini et al., 2018), which covers the period from 1981 to 2010 . The model fields were interpolated to the same grid as WOA18. Biases are defined as model values minus WOA18 values. For the multi-model mean, at each grid point we average $T_{\text {max }}, T_{\text {min }}, T_{\text {mean }}$ and $T_{\text {cycle }}$ across the 20 CMIP6 models. To quantify the performance of CMIP6 models, we calculated the area-weighted root mean square error of the model against WOA18 (henceforth RMSE) for global SST.

Since there is some uncertainty in observational climatologies because of sparse sampling, instrumental error, quality control or gridding techniques, we compared three recent climatologies: WOA18, WOCE-Argo Global Hydrographic Climatology (WAGHC)(Gouretski, 2018) (covering the time period 1985-2016), and HadISST (Rayner et al., 2003) (covering the time period 1981-2010). Any grid points where the maximum difference in $T_{\max }$ or $T_{\min }$ between the three climatologies is larger than $2^{\circ} \mathrm{C}$ are considered uncertain for that variable, and these grid points are excluded from our assessment. Any grid points which did not have values for all 12 months for at least two climatologies are also excluded. For $T_{\text {mean }}$ and $T_{c y c l e}$, we exclude 
https://doi.org/10.5194/os-2021-102

Preprint. Discussion started: 27 October 2021

(c) Author(s) 2021. CC BY 4.0 License.

Table 1. The 20 CMIP6 models used in this study; the horizontal resolution of their ocean component; ocean vertical coordinate (z: traditional height coordinate; $z^{*}$ : rescaled height coordinate for more accurate representation of free-surface variations; $\rho$ : isopycnic coordinate; $\sigma$ : terrain-following sigma coordinate; multiple symbols refer to a hybrid coordinate); total number of ocean vertical levels; thickness of the ocean top grid cell; and references.

\begin{tabular}{cccccc}
\hline Model & $\begin{array}{c}\text { Horizontal } \\
\text { resolution }\end{array}$ & $\begin{array}{c}\text { Vertical } \\
\text { coordinate }\end{array}$ & $\begin{array}{c}\text { Total } \\
\text { levels }\end{array}$ & $\begin{array}{c}\text { Top grid } \\
\text { thickness }\end{array}$ & References \\
\hline ACCESS-CM2 & $100 \mathrm{~km}$ & $z^{*}$ & 50 & $10 \mathrm{~m}$ & Bi et al. (2020) \\
ACCESS-ESM1-5 & $100 \mathrm{~km}$ & $z^{*}$ & 50 & $10 \mathrm{~m}$ & Law et al. (2017) \\
AWI-CM-1-1-MR & $25 \mathrm{~km}$ & $\mathrm{z}-\sigma$ & 46 & $5 \mathrm{~m}$ & Semmler et al. (2020) \\
BCC-CSM2-MR & $50 \mathrm{~km}$ & $\mathrm{z}$ & 40 & $10 \mathrm{~m}$ & Wu et al. (2019) \\
BCC-ESM1 & $50 \mathrm{~km}$ & $\mathrm{z}$ & 40 & $10 \mathrm{~m}$ & Wu et al. (2020) \\
CESM2 & $100 \mathrm{~km}$ & $\mathrm{z}$ & 60 & $10 \mathrm{~m}$ & Danabasoglu et al. (2020) \\
CanESM5 & $100 \mathrm{~km}$ & $\mathrm{z}$ & 45 & $6 \mathrm{~m}$ & Swart et al. (2019) \\
E3SM-1-0 & $50 \mathrm{~km}$ & $z^{*}$ & 60 & $10 \mathrm{~m}$ & Golaz et al. (2019) \\
GFDL-CM4 & $25 \mathrm{~km}$ & $z^{*}-\rho$ & 75 & $2 \mathrm{~m}$ & Held et al. (2019) \\
GISS-E2-1-G & $100 \mathrm{~km}$ & $\mathrm{z}$ & 40 & $10 \mathrm{~m}$ & Kelley et al. (2020) \\
GISS-E2-1-H & $100 \mathrm{~km}$ & $\mathrm{z}-\rho-\sigma$ & 32 & $10 \mathrm{~m}$ & Kelley et al. (2020) \\
HadGEM3-GC31-LL & $100 \mathrm{~km}$ & $z^{*}$ & 75 & $1 \mathrm{~m}$ & Andrews et al. (2020) \\
HadGEM3-GC31-MM & $25 \mathrm{~km}$ & $z^{*}$ & 75 & $1 \mathrm{~m}$ & Andrews et al. (2020) \\
INM-CM5-0 & $50 \mathrm{~km}$ & $\sigma$ & 40 & $7.3 \mathrm{~m}$ & Volodin et al. (2017) \\
IPSL-CM6A-LR & $100 \mathrm{~km}$ & $z^{*}$ & 75 & $2 \mathrm{~m}$ & Boucher et al. (2020) \\
MIROC6 & $100 \mathrm{~km}$ & $\mathrm{z}-\sigma$ & 62 & $2 \mathrm{~m}$ & Tatebe et al. (2019) \\
MPI-ESM1-2-HR & $50 \mathrm{~km}$ & $\mathrm{z}$ & 40 & $12 \mathrm{~m}$ & Müller et al. (2018) \\
NorESM2-MM & $100 \mathrm{~km}$ & $\rho$ & 53 & $2.5 \mathrm{~m}$ & Seland et al. (2020) \\
SAM0-UNICON & $100 \mathrm{~km}$ & $\mathrm{z}$ & 60 & $10 \mathrm{~m}$ & Park et al. (2019) \\
UKESM1-0-LL & $100 \mathrm{~km}$ & $z^{*}$ & 75 & $1 \mathrm{~m}$ & Sellar et al. (2019) \\
\hline
\end{tabular}

60 any points where either $T_{\max }$ or $T_{\min }$ is excluded. $4 \%, 3 \%, 4 \%$ and $4 \%$ of the ocean's surface area is excluded for $T_{\max }$, $T_{\text {min }}, T_{\text {mean }}$ and $T_{\text {cycle }}$ respectively. Similarly, for the timing of $T_{\max }$ and $T_{\min }$, any grid points which did not have values for at least two climatologies or their maximum difference between climatologies in timing is larger than 2 months are excluded. In our global maps, these points are masked, and in calculations of global and regional metrics, these points are excluded.

\section{Results and Discussion}

\section{3.1 Model representation of SST extrema}

For the multi-model mean, $T_{\max }$ and $T_{\min }$ have larger global RMSEs than $T_{\text {mean }}$ (Fig. 1), as SST biases with opposite signs in different seasons compensate each other when calculating the annual mean. Similarly, the $T_{\max }$ and $T_{\min }$ global RMSEs of the multi-model mean are smaller than the RMSEs of individual models (Figs. 1b-c, 2, 3). Therefore, a small bias in $T_{\text {mean }}$ 
https://doi.org/10.5194/os-2021-102

Preprint. Discussion started: 27 October 2021

does not guarantee a realistic $T_{\max }$ or $T_{\min }$; a small bias in a multi-model mean does not guarantee good performance of individual models.

The magnitudes of biases in $T_{\max }$ and $T_{\min }$ vary from model to model (Figs. 2, 3). The multi-model mean has RMSE less than $1^{\circ} \mathrm{C}$ in both $T_{\max }$ and $T_{\min }\left(0.89^{\circ} \mathrm{C}\right.$ and $0.87^{\circ} \mathrm{C}$ respectively). Most models have $T_{\max }$ and $T_{\min } \mathrm{RMSEs}$ between $1^{\circ} \mathrm{C}$ and $2^{\circ} \mathrm{C}$. Only HadGEM3-GC31-LL and GFDL-CM4 have $T_{\max } \mathrm{RMSE}$ less than $1{ }^{\circ} \mathrm{C}\left(0.94^{\circ} \mathrm{C}\right.$ and $0.93^{\circ} \mathrm{C}$ respectively). GISS-E2-1-H has the largest $T_{\max } \mathrm{RMSE}$ of $1.89^{\circ} \mathrm{C}$ and MIROC6 has the largest $T_{\min } \mathrm{RMSE}$ of $1.62^{\circ} \mathrm{C}$ (Figs. 2,3 ).

The bias in the timing of $T_{\max }$ and $T_{\text {min }}$ is within one month in most of the global ocean in most models (Figs. 4, 5, 6). In the multi-model mean, $T_{\max }$ and $T_{\min }$ occur one month earlier than in WOA18 for most of the global ocean, whereas in some parts of the Arabian Sea and equatorial regions, they occur one month later (Fig. 4). It demonstrates that seasonal cycles in CMIP6 models are out of phase with observations. In regions where monsoon prevails (e.g. the northwestern Indian Ocean), the timing bias suggests a bias in the onset of summer monsoon.

$T_{\max }$ and $T_{\min }$ biases vary with latitude (Figs. 1b-c, 2, 3, 7g-h). Typically, the RMSE of $T_{\max }$ at $30^{\circ}-80^{\circ}$ is $1-2^{\circ} \mathrm{C}$ larger than at low latitudes (between $30^{\circ} \mathrm{N}$ and $30^{\circ} \mathrm{S}$ ) (Fig. 7g). For GISS-E2-1-H, GISS-E2-1-G, BCC-CSM2-MR, BCC-ESM1 and IPSL-CM6A-LR, $T_{\max }$ RMSEs at $30^{\circ} \mathrm{N}-80^{\circ} \mathrm{N}$ are about $3^{\circ} \mathrm{C}$ larger than at low latitudes. A similar pattern is seen for $T_{m i n}$, but the variation of biases with latitude is much smaller than for $T_{\max }$ (Fig. 1c, 7h). Flato et al. (2013) found a similar result for some CMIP5 models, with larger zonal mean biases in $T_{\text {mean }}$ between $30^{\circ}$ and $70^{\circ}$ than at other latitudes. The larger biases, and greater difference between $T_{\max }$ and $T_{\min }$, at mid-high latitudes (greater than $30^{\circ}$ in both hemispheres) may be explained by the large seasonal cycle of mixed layer depth there. Shallower summer mixed layers have smaller heat capacity, thus a small error in heat fluxes or mixing processes can result in a large bias for $T_{\max }$, though this will be modulated by any seasonal biases in mixed layer depth. The larger inter-model biases in $T_{\max }$ than in $T_{\min }$ can be explained by the shallower mixed layer in summer, which can amplify SST biases due to biases in surface heat flux. The difference between biases in $T_{\max }$ and $T_{\min }$ leads to biases in $T_{\text {cycle }}$ (Fig. 1d). The RMSE of $T_{\text {cycle }}$ at low latitudes is typically $1^{\circ} \mathrm{C}$, whereas at mid-high latitudes it is larger, particularly in the Northern Hemisphere (Fig. 7i). The $T_{c y c l e}$ RMSE in IPSL-CM6A-LR and MIROC6 reaches $4^{\circ} \mathrm{C}$ at high latitudes (Fig. 7i).

In polar regions, there are very small $T_{\min }$ biases (Figs. 1c, 3, 7h) except for MIROC6 in the Antarctic. Winter SSTs are close to freezing, but cannot go below freezing because sea ice forms instead. If models have realistic freezing points, $T_{m i n}$ biases will be small. Some models have salinity-dependent freezing points (Beaumet et al., 2019) in which case a salinity bias could cause a bias in temperature. $T_{\text {min }}$ biases in the Arctic are larger than in the Antarctic (Figs. 1c, 7e-f), which suggests larger saline biases in the Arctic.

In the subtropical North Pacific, the SST cold bias is typically $0.5-1^{\circ} \mathrm{C}$ smaller in $T_{\max }$ than $T_{\min }$, which leads to a too large $T_{\text {cycle }}$ (Figs. 1b-d, 2, 3). Zhu et al. (2020) showed a similar seasonal SST cold bias in the CMIP6 multi-model mean, but not in the CMIP5 multi-model mean. Underestimated surface shortwave radiation and too strong westerly winds in the CMIP6 multi-model mean (Lyu et al., 2020; Li et al., 2020) are possible reasons for the year round cold bias. The shortwave radiation bias is likely related to the bias of low-level cloud in the subtropics (Burls et al., 2017; Li and Xie, 2012), and its associated cold bias is smaller in winter when there is less solar radiation. The westerly winds cool the surface through latent heat flux 

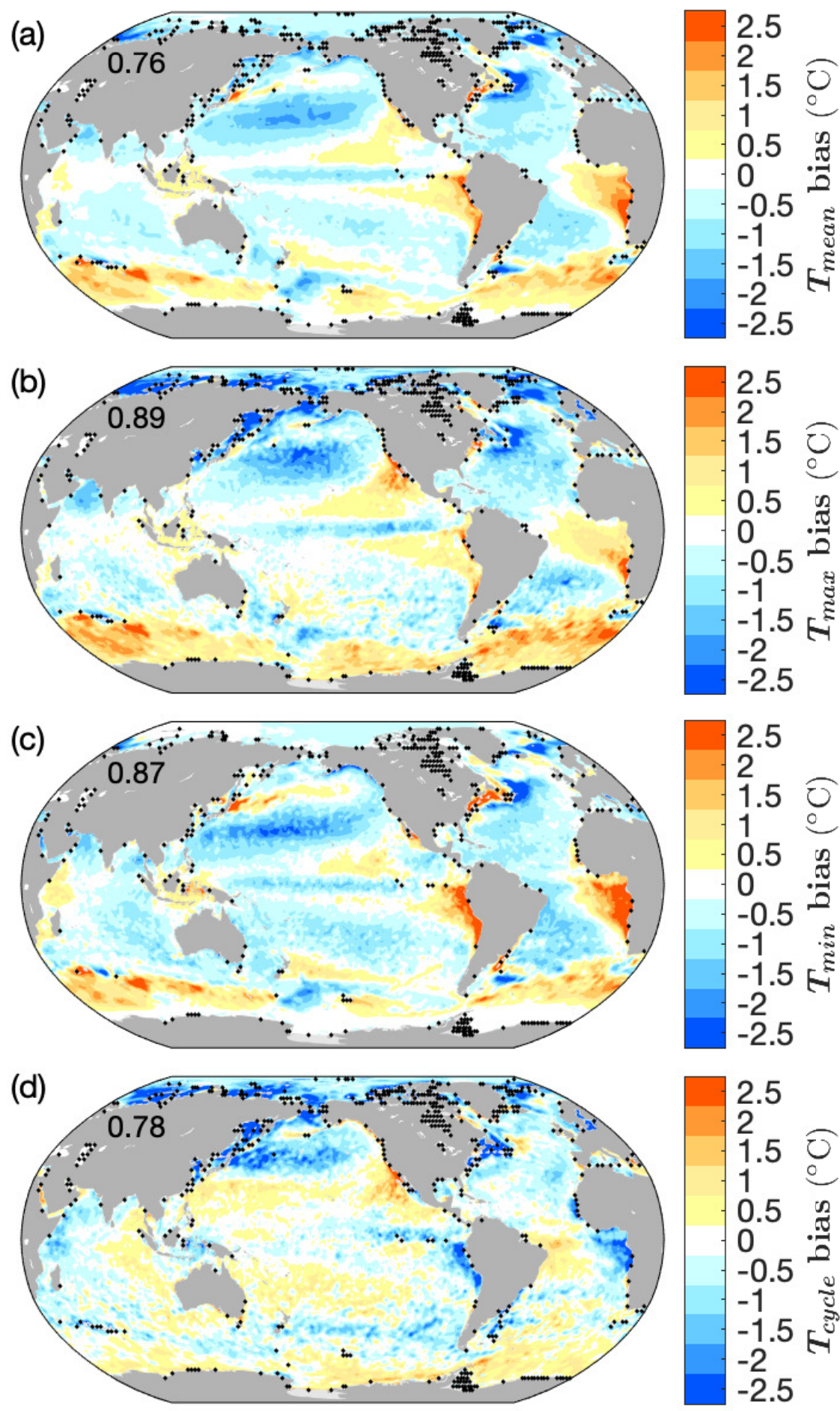

Figure 1. Biases (model minus climatology) of multi-model mean in (a) $T_{\text {mean }}$ (b) $T_{\max }$ (c) $T_{\min }$ (d) $T_{\text {cycle. Black dots mark grid points }}$ excluded from our analysis, as described in section 2 . The numbers indicate the global RMSE $\left({ }^{\circ} \mathrm{C}\right)$. 

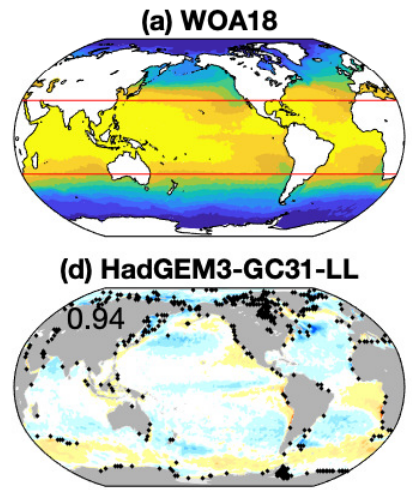

(g) HadGEM3-GC31-MM

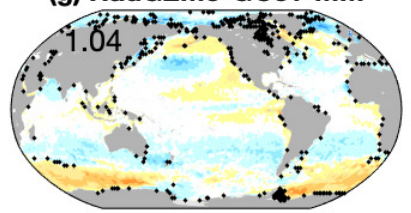

(j) MPI-ESM1-2-HR

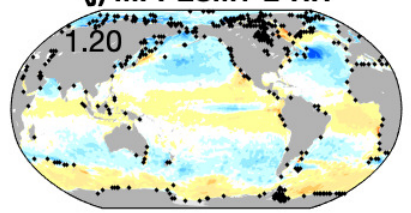

(m) MIROC6

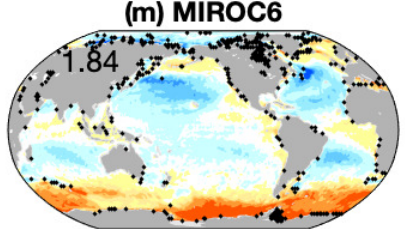

(p) BCC-CSM2-MR

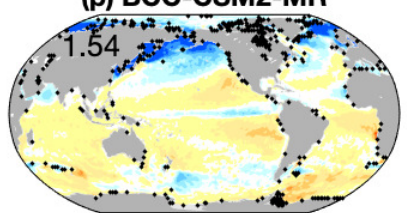

(s) GISS-E2-1-H

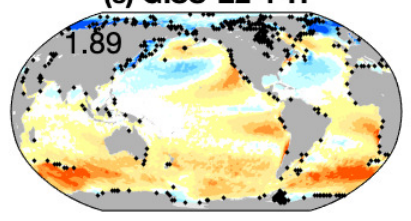

$-2$ (b) AWI-CM-1-1-MR

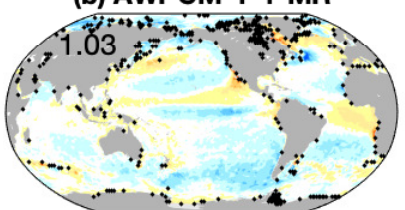

(e) SAMO-UNICON

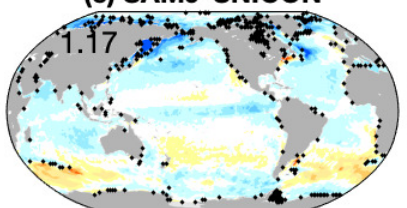

(h) E3SM-1-0

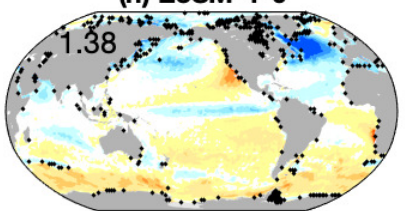

(k) INM-CM5-0

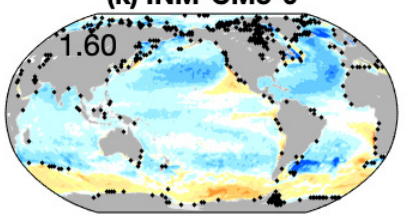

(n) ACCESS-CM2

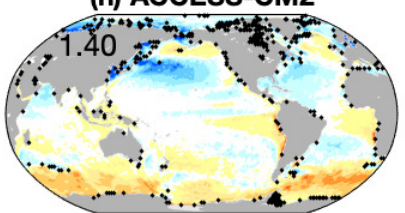

(q) BCC-ESM1

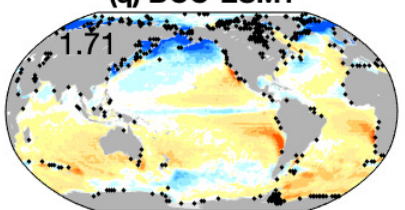

(t) IPSL-CM6A-LR

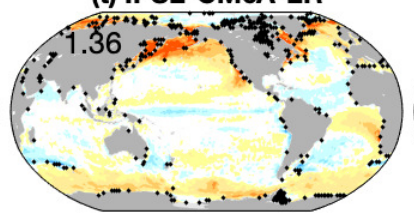

$-5-4-3$ (c) UKESM1-0-LL

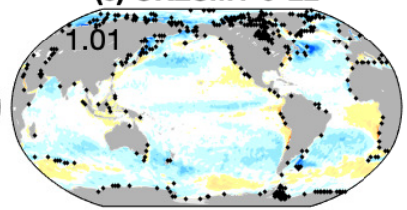

(f) GFDL-CM4

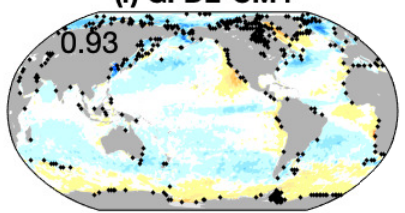

(i) NorESM2-MM

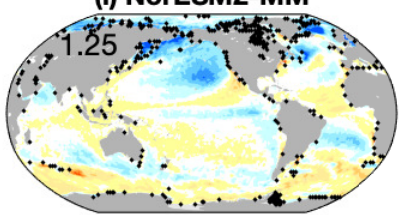

(I) CanESM5

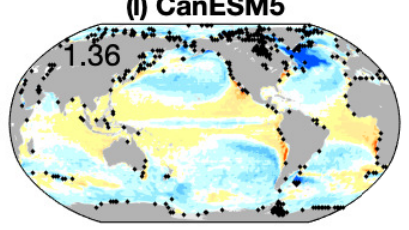

(o) CESM2

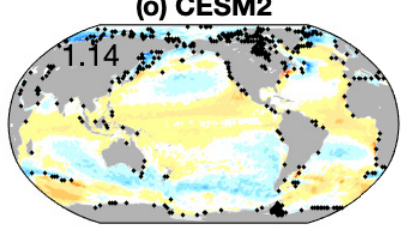

(r) GISS-E2-1-G

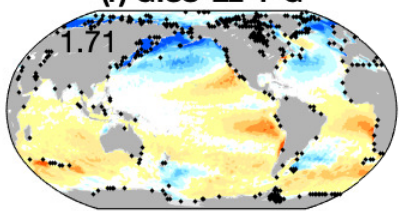

(u) ACCESS-ESM1-5

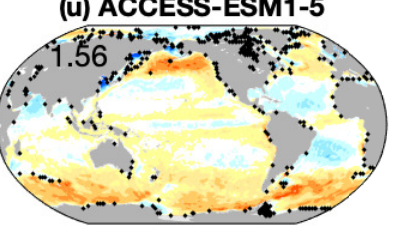

$T_{\text {max }}$ bias $\left({ }^{\circ} \mathrm{C}\right)$

Figure 2. (a) $T_{\max }$ in WOA18 and (b-u) $T_{\max }$ model biases. Black dots mark grid points excluded from our analysis, as described in section 2. The numbers on (b-u) indicate the global RMSE of $T_{\max }$. Red lines in (a) are $30^{\circ} \mathrm{N}$ and $30^{\circ} \mathrm{S}$. Note that the range of bias color bar is twice as much as in Fig. 1 . 


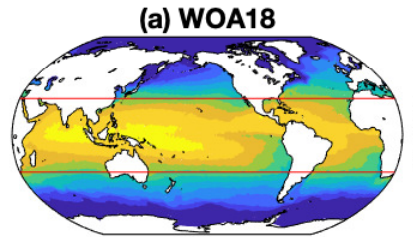

(d) HadGEM3-GC31-LL

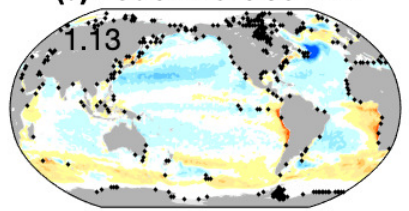

(g) HadGEM3-GC31-MM

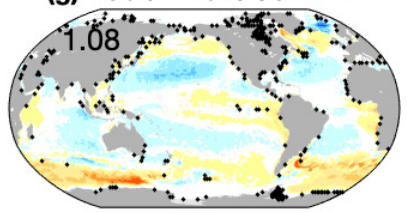

(j) MPI-ESM1-2-HR

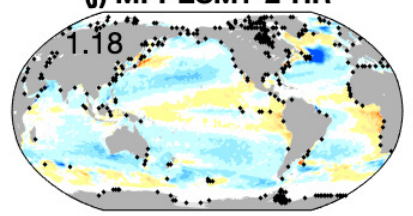

(m) MIROC6

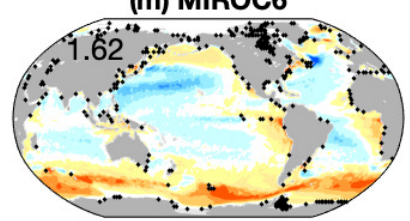

(p) BCC-CSM2-MR

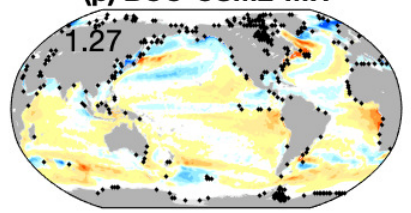

(s) GISS-E2-1-H

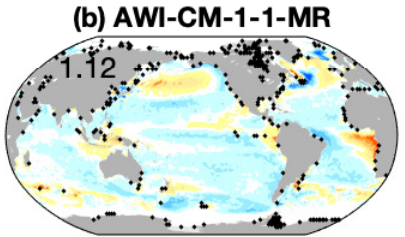

(e) SAMO-UNICON

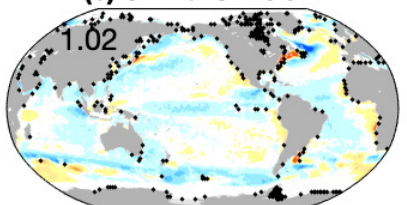

(h) E3SM-1-0

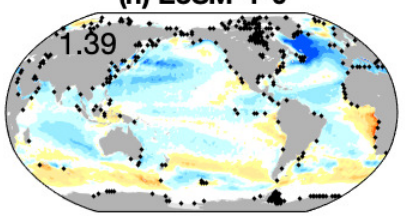

(k) INM-CM5-0

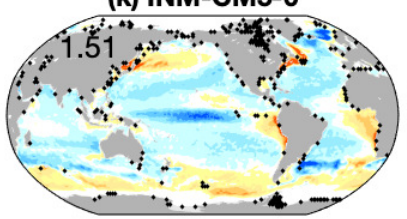

(n) ACCESS-CM2

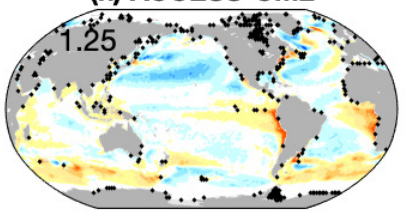

(q) BCC-ESM1

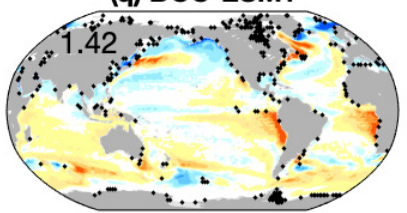

(t) IPSL-CM6A-LR
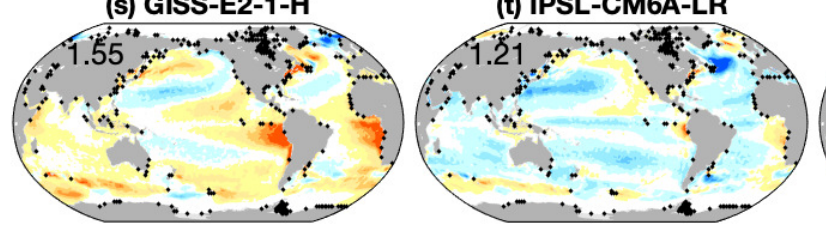

(c) UKESM1-0-LL

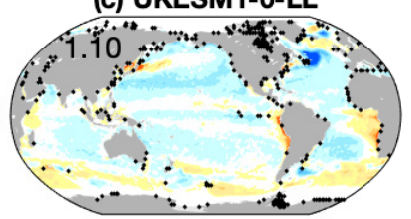

(f) GFDL-CM4

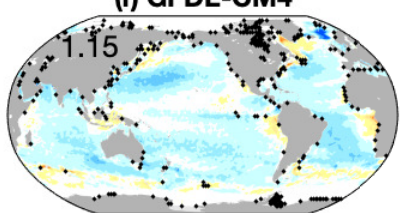

(i) NorESM2-MM
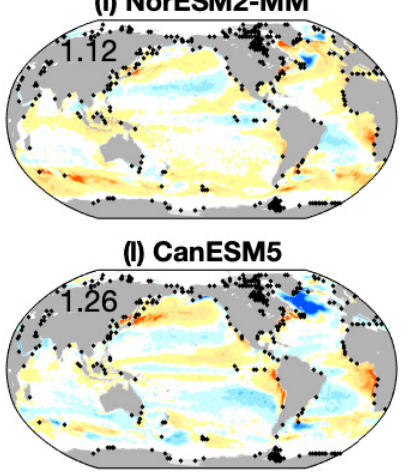

(o) CESM2

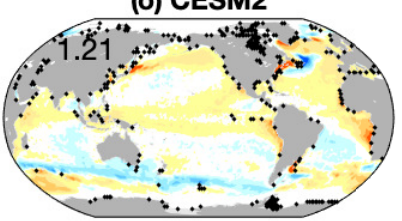

(r) GISS-E2-1-G

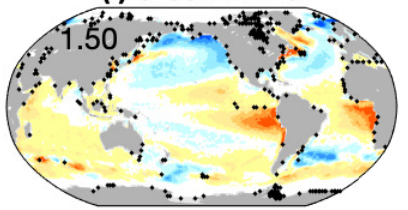

(u) ACCESS-ESM1-5

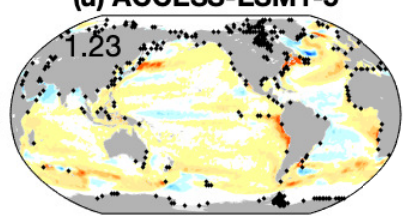

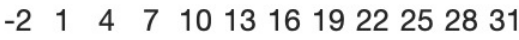
$T_{\min }\left({ }^{\circ} \mathrm{C}\right)$

$T_{\min }$ bias $\left({ }^{\circ} \mathrm{C}\right)$

Figure 3. As in Fig. 2, but for $T_{m i n}$. 
(a)

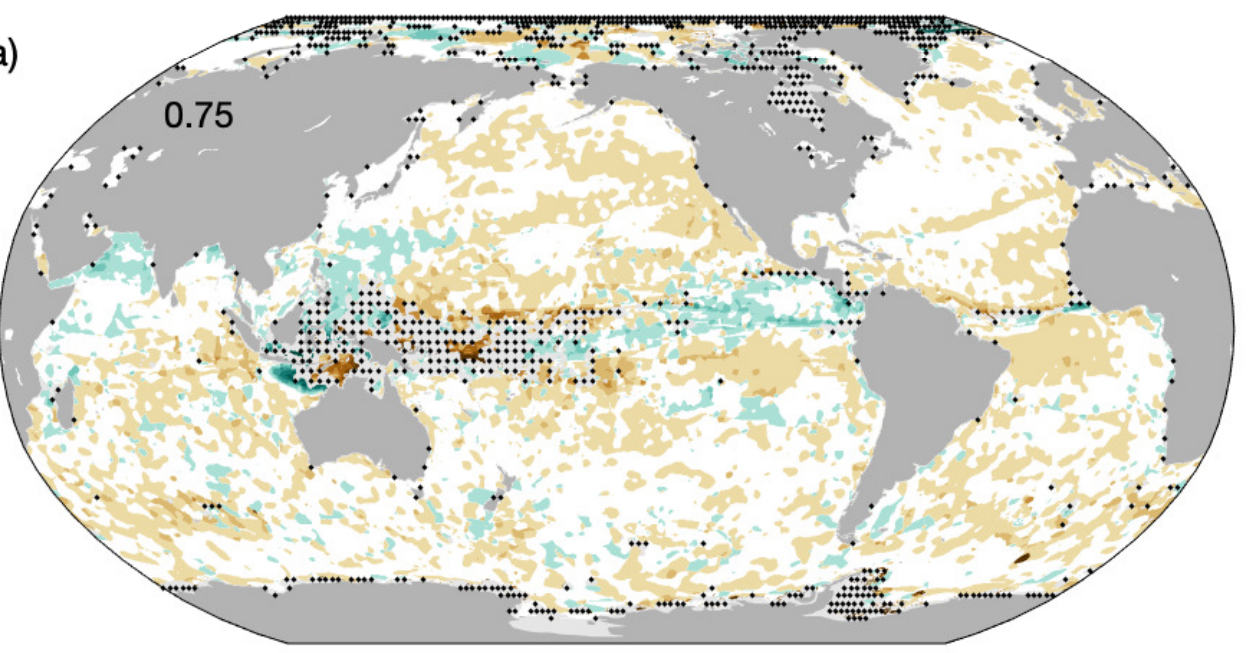

(b)
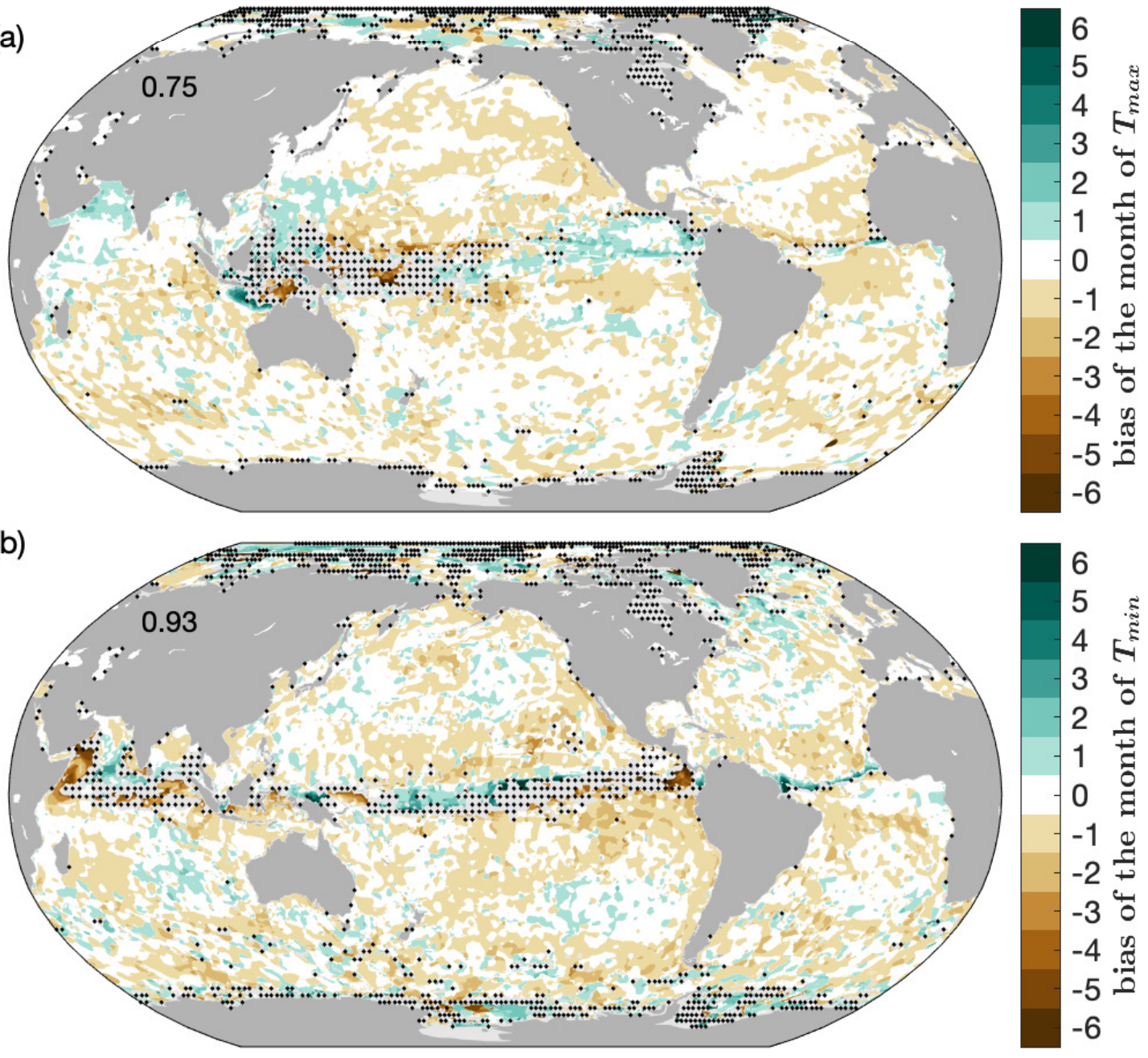

Figure 4. Biases in the timing of (a) $T_{\max }$ and (b) $T_{\min }$ in the multi-model mean. Black dots mark grid points excluded from our analysis, as described in section 2 . 
(a) WOA18

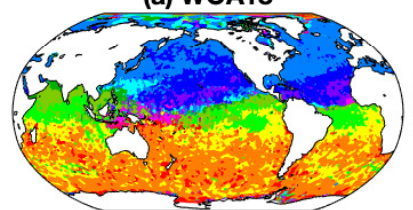

(d) HadGEM3-GC31-LL

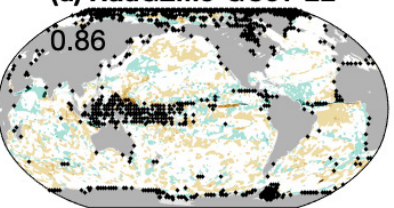

(g) HadGEM3-GC31-MM

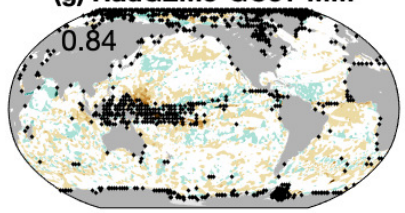

(j) MPI-ESM1-2-HR

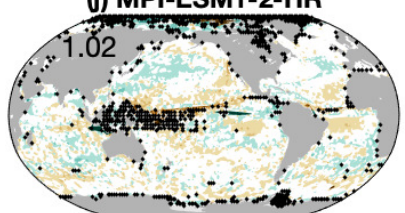

(m) MIROC6

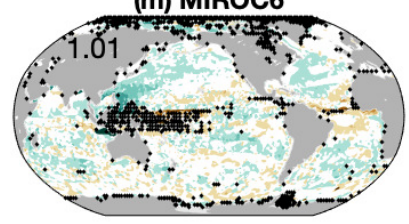

(p) BCC-CSM2-MR

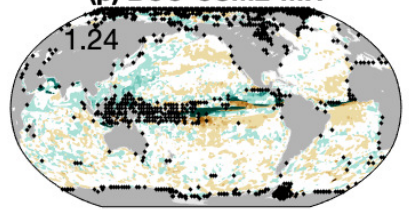

(s) GISS-E2-1-H

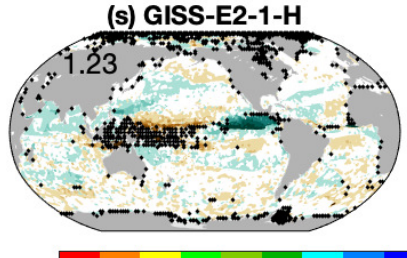

J F M A M J J A S O N D month of $T_{\max }$ (b) AWI-CM-1-1-MR

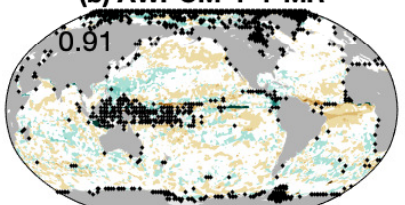

(e) SAMO-UNICON

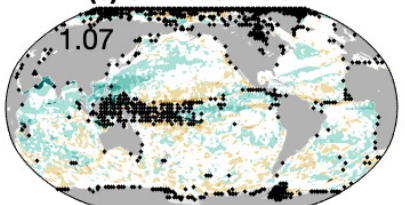

(h) E3SM-1-0
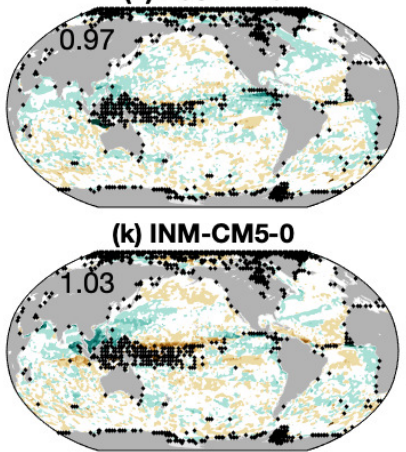

(n) ACCESS-CM2

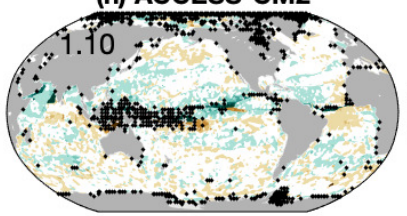

(q) BCC-ESM1

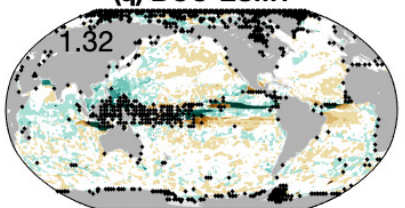

(t) IPSL-CM6A-LR
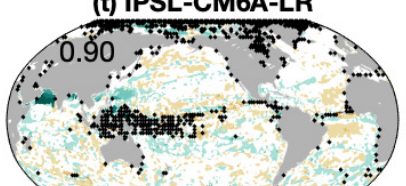

$+\cdots-2,-2$

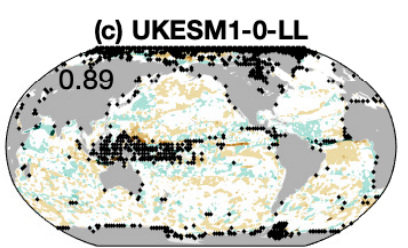

(f) GFDL-CM4

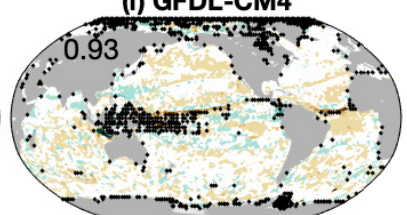

(i) NorESM2-MM

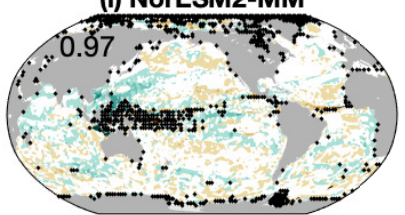

(l) CanESM5

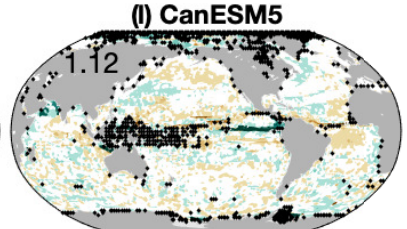

(o) CESM2

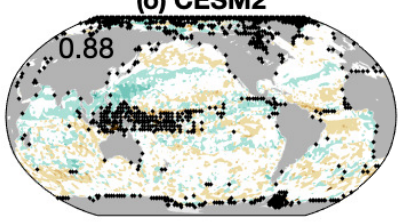

(r) GISS-E2-1-G

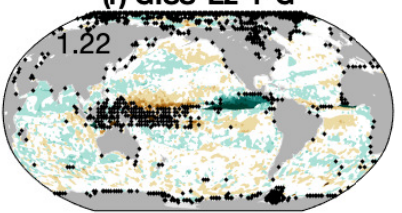

(u) ACCESS-ESM1-5

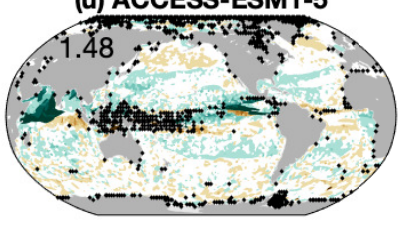

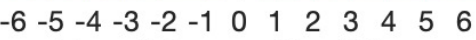

bias of the month of $T_{\max }$

Figure 5. (a) Timing of $T_{\max }$ in WOA18 and (b-u) biases in the timing of $T_{\max }$ in models. Black dots mark grid points excluded from our analysis, as described in section 2 . 


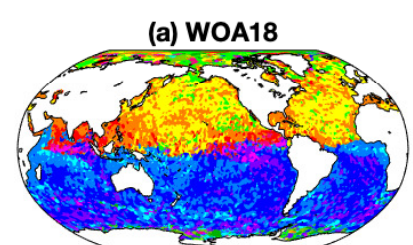

(d) HadGEM3-GC31-LL

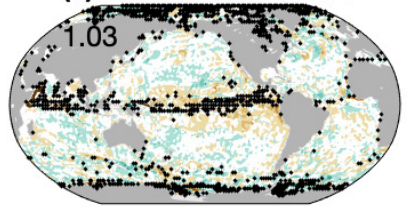

(g) HadGEM3-GC31-MM

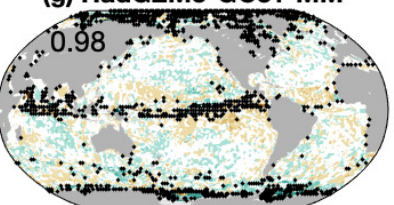

(j) MPI-ESM1-2-HR

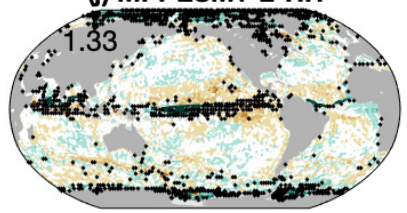

(m) MIROC6

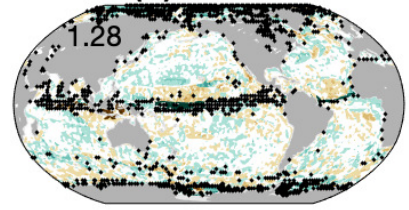

(p) BCC-CSM2-MR

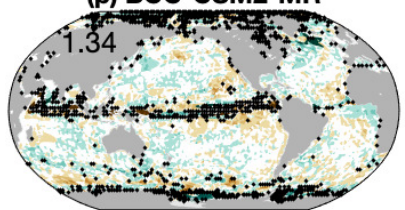

(s) GISS-E2-1-H

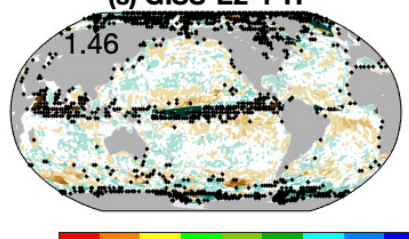

$J F M A M J J A O N D$ month of $T_{m i n}$ (b) AWI-CM-1-1-MR

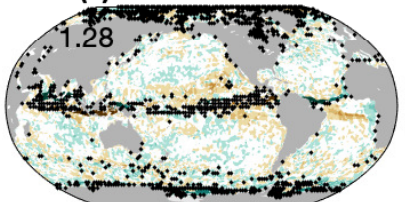

(e) SAMO-UNICON

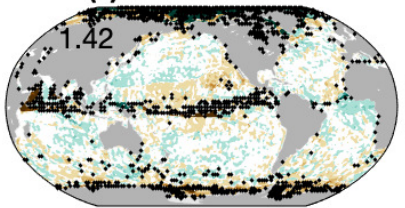

(h) E3SM-1-0

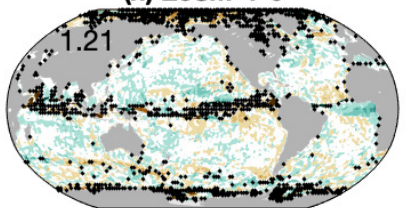

(k) INM-CM5-0

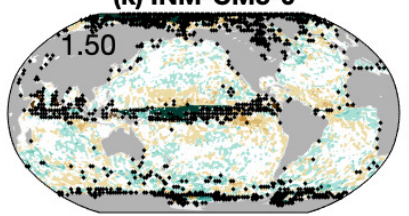

(n) ACCESS-CM2

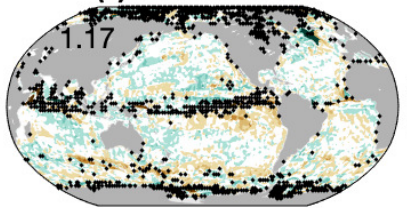

(q) BCC-ESM1

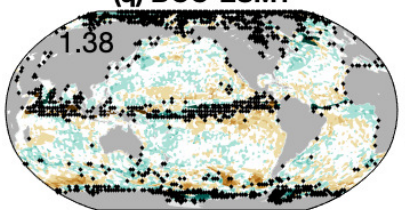

(t) IPSL-CM6A-LR

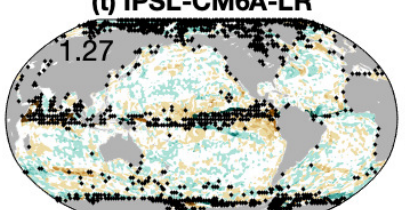

(c) UKESM1-0-LL

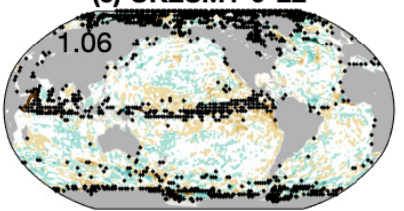

(f) GFDL-CM4

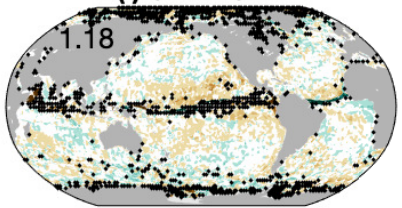

(i) NorESM2-MM

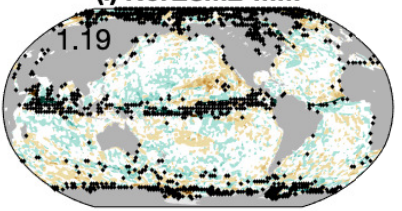

(I) CanESM5

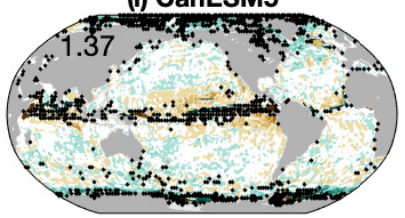

(o) CESM2

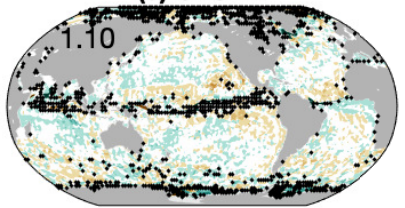

(r) GISS-E2-1-G

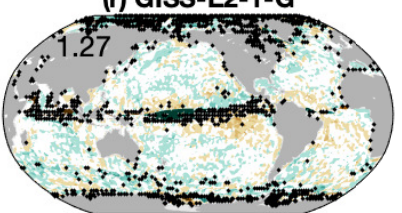

(u) ACCESS-ESM1-5

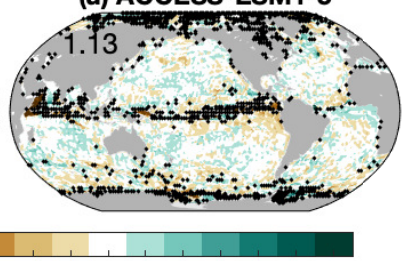

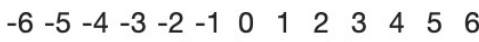
month of $T_{\min }$ bias

Figure 6. As in Fig. 5, but for timing of $T_{\min }$. 
https://doi.org/10.5194/os-2021-102

Preprint. Discussion started: 27 October 2021
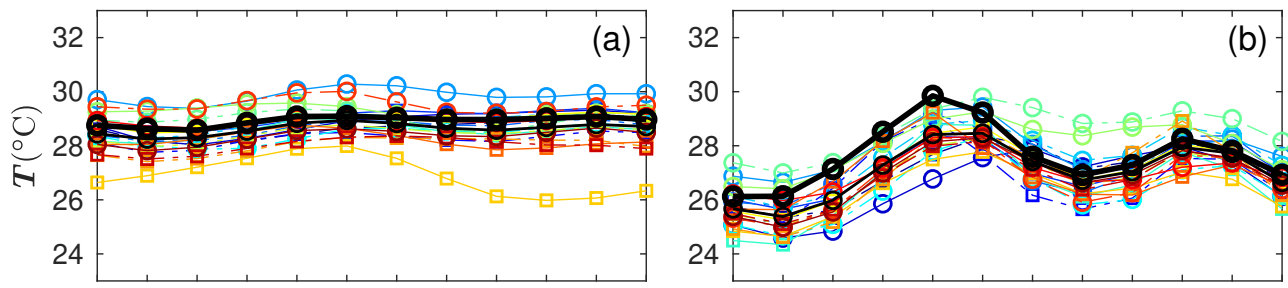

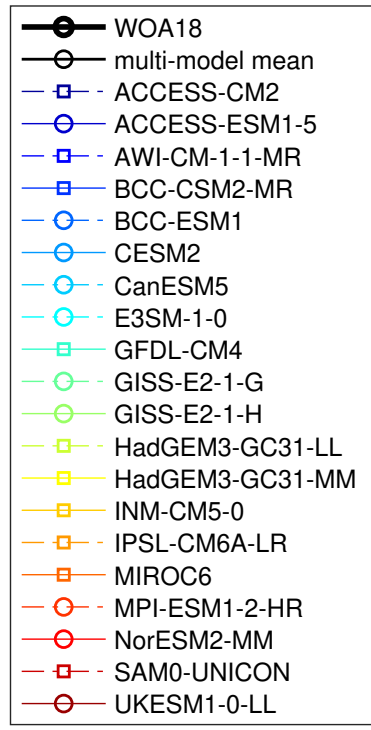
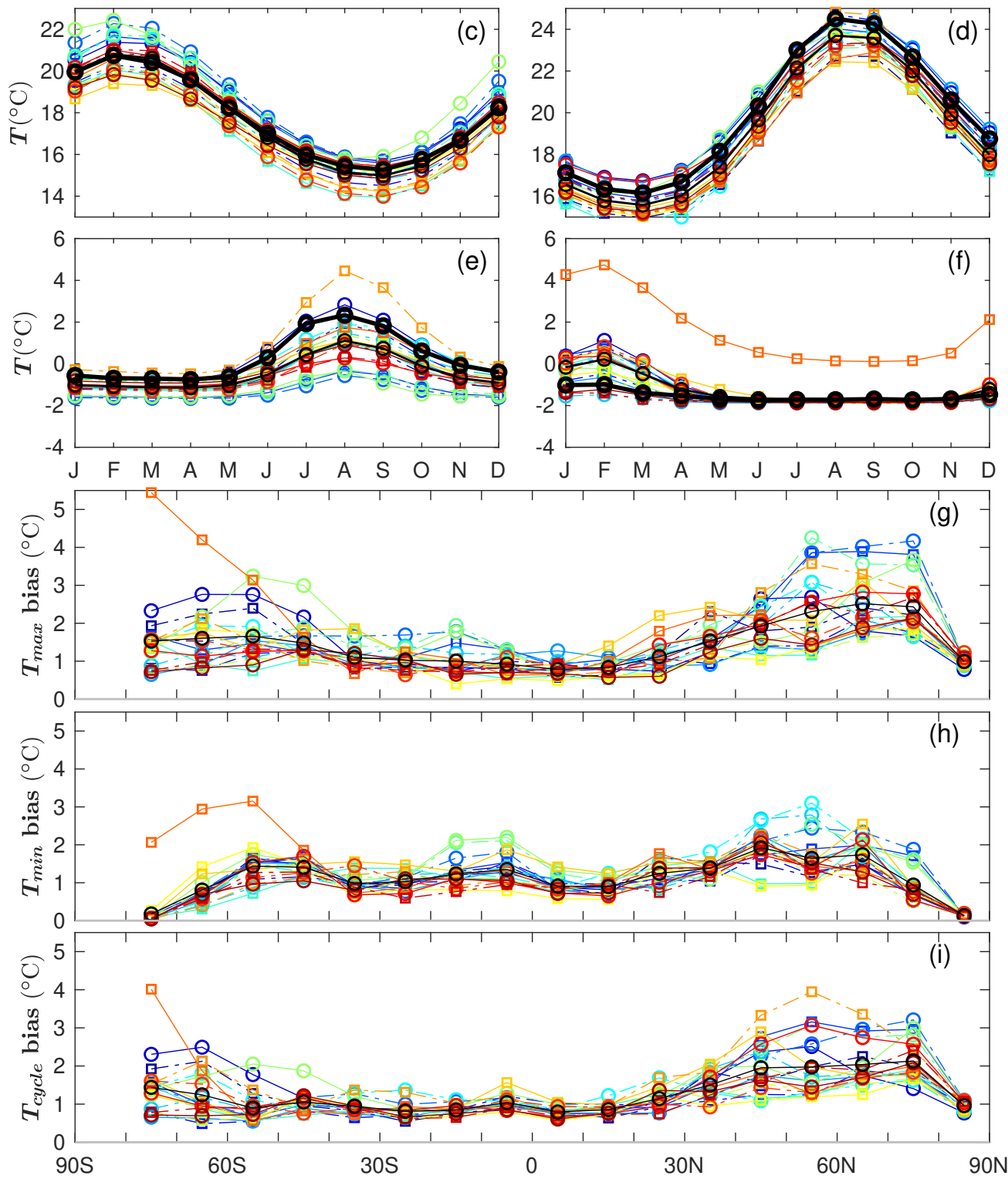

Figure 7. Monthly time series of area-weighted mean SST over (a) western equatorial Pacific $\left(5^{\circ} \mathrm{S}-5^{\circ} \mathrm{N}, 140^{\circ} \mathrm{E}-160^{\circ} \mathrm{W}\right)$, (b) northwestern Indian Ocean $\left(60-70^{\circ} \mathrm{E}, 10-20^{\circ} \mathrm{N}\right)$, (c) subtropical Southern Hemisphere $\left(30^{\circ}-40^{\circ} \mathrm{S}\right)$, (d) subtropical Northern Hemisphere $\left(30-40^{\circ} \mathrm{N}\right)$, (e) Arctic $\left(70-80^{\circ} \mathrm{N}\right)$, (f) Antarctic $\left(70-80^{\circ} \mathrm{S}\right)$, and area-weighted RMSE in $10^{\circ}$ bands for $(\mathrm{g}) T_{\max }$, (h) $T_{\min }$, (i) $T_{c y c l e}$. Y-axis range is same for (a-f). 
https://doi.org/10.5194/os-2021-102

Preprint. Discussion started: 27 October 2021

and southward ocean advection due to Ekman transport. The latent heat loss is larger in summer (Yu, 2007), while the ocean heat advection is larger in winter when meridional SST gradients are greater.

SST biases are seasonally dependent in the northeastern Pacific Inter Tropical Convergence Zone (ITCZ) (Figs. 1b-c, 2, 3). For the multi-model mean, there is a warm bias in $T_{\max }$ which exceeds $2^{\circ} \mathrm{C}$ and a cold bias in $T_{\min }$ of $0.5-1.5^{\circ} \mathrm{C}$. Similar seasonal biases exist in CMIP5 models and were linked to an easterly wind bias throughout the year there (Song and Zhang, 2020). A coarse atmospheric model resolution smooths out the elevation difference between mountains and oceans, which allows easterly trade winds to cross the mountains, leading to the easterly wind bias (Song and Zhang, 2020). An easterly bias of annual mean wind was found in the CMIP6 multi-model mean (Li et al., 2020; Lyu et al., 2020). If the easterly bias exists throughout the year, it can explain the seasonal SST bias we found. During winter-spring, the northeastern Pacific ITCZ is dominated by easterly winds, so overly strong easterly winds enhance surface evaporation and lead to cold biases. In contrast, during summer-autumn when westerly winds dominate, the simulated wind is too weak, which causes the warm bias. The northeastern Pacific is a region where tropical cyclones and heatwaves occur (Gilford et al., 2017; Frölicher and Laufkötter, 2018), so a warm bias of over $2^{\circ} \mathrm{C}$ in $T_{\max }$ may lead to overprediction of tropical cyclones and heatwaves.

The multi-model mean has a cold bias in $T_{\max }$ and a warm bias in $T_{\min }$ over the Northwest Pacific, leading to a too small $T_{\text {cycle }}$ (bias of more than $2^{\circ} \mathrm{C}$ ) (Figs. 1b-d). The warm bias in winter can be seen in many models, especially in ACCESSESM1-5, BCC-ESM1, CanESM5 and INM-CM5-0 (Fig. 3). Models with a warm bias in $T_{\min }$ are likely to generate overly intense winter storms, as warm SSTs will increase the storm energy source. Greeves et al. (2007) demonstrated that there was a clear link in the Hadley Centre models between winter SST warm bias to the east of Japan and increased storm intensity in the region. The winter warm bias east of Japan was also found in a CMIP5 multi-model mean (Wang et al., 2018), but from our results the warm bias extends further east (Fig. 1c).

The large cold biases at northern hemisphere high latitudes in BCC-CSM2-MR, BCC-ESM1, GISS-E2-1-G and GISS-E21-H, are typically $2-5^{\circ} \mathrm{C}$ smaller in $T_{\min }$ than in $T_{\max }$ (Figs. $2,3,7 \mathrm{~g}-\mathrm{h}$ ). These cold biases have been previously linked to cloud biases. The negative cloud radiative forcing is excessive in BCC-CSM2-MR (Wu et al., 2019) and BCC-ESM1 (cloud simulation likely to be similar to BCC-CSM2-MR), while overestimated low-cloud cover in GISS-E2-1-G and GISS-E2-1-H (Kelley et al., 2020) blocks more of the incoming solar radiation. As solar radiation is negligible at high latitudes in winter, the SST cold bias due to cloud bias is much smaller in winter than in summer, consistent with our results. Deep winter mixed layer depths and SSTs close to freezing likely also contribute to the smaller cold biases in $T_{\min }$ than in $T_{\max }$ at high latitudes.

In most models there is a warm $T_{\text {mean }}$ bias in the Southern Ocean, commonly attributed to excessive short wave radiation linked to underestimated cloud (Hyder et al., 2018). MIROC6 has an underestimated mid-level cloud cover (Tatebe et al., 2019); GISS-E2-1-G and GISS-E2-1-H have an underestimated short wave cloud radiative forcing (Kelley et al., 2020), and hence they have pronounced warm biases in the Southern Ocean (Figs. 2, 3). The warm bias is larger for $T_{\max }$ than $T_{\min }$ (Figs. 1b-c, 2, 3, 7g-h), because the lack of incoming solar radiation in winter means cloud biases have minimal effect on surface solar insolation. Shallower mixed layer depths in summer will also tend to enhance any bias in incoming solar insolation. The larger warm bias in $T_{\max }$ than $T_{\min }$ results in a sea ice extent that is too small in most CMIP6 models, especially in summer 
https://doi.org/10.5194/os-2021-102

Preprint. Discussion started: 27 October 2021

(Beadling et al., 2020; Shu et al., 2020). As mode and intermediate waters primarily form within the winter mixed layer of the Antarctic Circumpolar Current (Talley, 1999), the $T_{\min }$ warm bias can influence global ocean stratification.

MIROC6 stands out with the largest warm bias in the Southern Ocean (Figs. $2 \mathrm{~m}, 3 \mathrm{~m}$ ), with a $T_{\max }$ RMSE between 3 and $5^{\circ} \mathrm{C}$ and $T_{\min }$ RMSE between 2 and $3^{\circ} \mathrm{C}$ at 50-80 $\mathrm{S}$ (Fig. $7 \mathrm{~g}$ ). The largest biases in MIROC6 occur in regions where there should be sea ice and where the deep ocean is ventilated. Beadling et al. (2020) found that MIROC6 has the lowest Southern Ocean sea ice extent among CMIP6 models in both summer and winter, and Tatebe et al. (2019) revealed annual warm biases exceeding $2^{\circ} \mathrm{C}$ in the intermediate and deep layers of MIROC6.

In eastern boundary upwelling regions (especially the Benguela and Humboldt Currents), most models have a seasonal warm bias that is $1-5^{\circ} \mathrm{C}$ smaller in $T_{\max }$ than $T_{\min }$ (Figs. 1b-c, 2, 3). Richter (2015) suggested that underestimation of stratocumulus cloud and insufficient upwelling due to overly weak winds contribute to the warm bias in eastern boundary upwelling regions. The warm bias we found therefore is likely associated with the underestimated surface shortwave radiation and overly weak upwelling-favourable winds in CMIP6 models identified by Li et al. (2020). The warm bias may lead to excessive precipitation in the Atlantic Ocean off Angola and Namibiaas as shown by Rouault et al. (2003). Letelier et al. (2009) showed that in the Humboldt Current coastal region the cooling effect of upwelling is strongest in austral summer, which is consistent with the peak of upwelling-favourable wind in December and January. A poor simulation of the seasonal cloud and upwelling processes will contribute to the seasonality of SST biases in eastern boundary upwelling regions.

Most models have a seasonal warm SST bias in the eastern equatorial Atlantic (Figs. 1b-c, 2 and 3). The $T_{m i n}$ multi-model mean bias can be more than $2^{\circ} \mathrm{C}$ larger than the $T_{\max }$ multi-model mean bias. Richter and Tokinaga (2020) showed a similar seasonal warm bias in the CMIP6 multi-model mean, which is about $1-2^{\circ} \mathrm{C}$ larger during June-July-August than March-AprilMay. Richter et al. (2012) argued that the warm SST bias in the eastern equatorial Atlantic during June-July-August is linked to overly deep thermoclines caused by overly weak easterlies during March-April-May. Therefore, the warm bias can be attributed to overly weak easterlies in the CMIP6 multi-model mean (Li et al., 2020; Lyu et al., 2020). GISS-E2-1-G and GISS-E2-1-H have the largest seasonality of SST warm bias in the eastern equatorial Atlantic, with $T_{\min }$ biases up to $5^{\circ} \mathrm{C}$. Richter and Tokinaga (2020) illustrated that warmer than observed SSTs in the equatorial Atlantic lead to excessive precipitation. Roxy (2014) quantified the SST-precipitation relationship: a $1^{\circ} \mathrm{C} \mathrm{SST}$ increase corresponds to a $2 \mathrm{~mm} /$ day precipitation increase. Therefore, the $5^{\circ} \mathrm{C} T_{\min }$ warm bias in GISS-E2-1-G and GISS-E2-1-H could cause a $10 \mathrm{~mm} /$ day increase in precipitation.

Although the amplitudes of biases are different in $T_{\max }$ and $T_{\min }$, the global patterns and signs of $T_{\max }$ and $T_{\min }$ biases are similar to each other in most models (Figs. 2, 3). Wang et al. (2014) indicated that the SST bias of the CMIP5 multi-model mean has a pattern independent of season but did not analyse the seasonality in bias in individual models. Our results show two exceptions: E3SM-1-0 and IPSL-CM6A-LR, which both have an overall warm bias in $T_{\max }$, but an overall cold bias in $T_{\text {min }}$ (Figs. 2h,t 3h,t), which tend to cancel out in the annual means. The $T_{\max } \mathrm{RMSE}$ is $1.38^{\circ} \mathrm{C}$ for $\mathrm{E} 3 \mathrm{SM}-1-0$ and $1.36^{\circ} \mathrm{C}$ for IPSL-CM6A-LR, the $T_{\min } \mathrm{RMSE}$ is $1.39^{\circ} \mathrm{C}$ for E3SM-1-0 and $1.21^{\circ} \mathrm{C}$ for IPSL-CM6A-LR, whereas the $T_{m e a n} \mathrm{RMSE}$ is only $1.17{ }^{\circ} \mathrm{C}$ for E3SM-1-0 and $0.94^{\circ} \mathrm{C}$ for IPSL-CM6A-LR. In E3SM-1-0, the global annual average mixed layer depth is generally too shallow (Golaz et al., 2019), which can contribute to the summer SST warm bias and winter SST cold bias, and 
https://doi.org/10.5194/os-2021-102

Preprint. Discussion started: 27 October 2021

(c) Author(s) 2021. CC BY 4.0 License.

a similar process may be affecting IPSL-CM6A-LR. These results illustrate the risks involved in assessing only annual means, as models may have greater biases than assumed, so tropical cyclone formation, for example, may be overpredicted.

In mid-latitudes the SST seasonal cycle is well represented by an annual sinusoid whereas in equatorial and polar regions an annual sinusoid explains little of the total SST seasonal variance (Trenberth, 1983; Yashayaev and Zveryaev, 2001). In regions with fairly sinusoidal SST annual cycles such as the subtropics, models have realistic SST seasonal cycles with well simulated amplitude and phase of the annual cycle (Figs. 7c-d). Phase biases are mainly within 1 month (Figs. 4, 5, 6). In subtropical regions, seasonal SST biases are consistent with biases in $T_{\text {mean }}$. Differences between the $T_{\max }$ and $T_{\min }$ biases are smaller than those in non-sinusoidal regions (Fig. 7). In regions with non-sinusoidal SST seasonal cycles such as the western equatorial Pacific, northwestern Indian Ocean, the Arctic and the Antarctic, models tend to have biases in amplitudes or phases of their SST seasonal cycles (Figs. 4, 5, 6, 7a-b,e-f).

In the western equatorial Pacific, the SST seasonal cycle in WOA18 is modest (less than $1^{\circ} \mathrm{C}$ ), whereas in some models such as MPI-ESM1-2-HR, GISS-E2-1-G, GISS-E2-1-H and especially INM-CM5-0 the seasonal cycle is much larger (Fig. 7a). In INM-CM5-0, the $T_{\text {cycle }}$ is about $2^{\circ} \mathrm{C}$ and there is a cold SST bias throughout the year, reaching $3{ }^{\circ} \mathrm{C}$ during SeptemberOctober-November (Fig. 7a). Similar to our analysis, Volodin et al. (2017) noted that INM-CM5-0 has a cold bias of more than $4^{\circ} \mathrm{C}$ in annual mean temperature in the upper $700 \mathrm{~m}$ of the western equatorial Pacific. The cold bias could limit the skills of models in simulation of El Niño/Southern Oscillation (ENSO) and ENSO-induced teleconnections. For example, a cold bias in the western equatorial Pacific results in a rising branch of the Walker circulation that is too far west in many coupled climate models leading to too weak ocean-atmosphere coupling and unrealistic ENSO dynamics (Bayr et al., 2018). The associated convective response along the equator during ENSO events is too far west leading to westward shift in the sea level pressure response in the North Pacific and precipitation response in the subtropics (Bayr et al., 2019).

In the northwestern Indian Ocean where the monsoon system prevails, SST has a semi-annual cycle, but most models are unable to reproduce this with the correct amplitude and phase (Figs. 4, 5, 6, 7b). Most CMIP6 models have SST cold biases in this region throughout the year, while the biases are generally larger during March-April-May than other months and the multimodel mean fails to simulate the primary maximum SST (Fig. 7b). Cold SST biases in the northwestern Indian Ocean lead to a significant reduction of the monsoon rainfall over the Indian subcontinent (Prodhomme et al., 2014; Levine and Turner, 2012). Thus the cold biases in the CMIP6 models are likely to lead to overly weak monsoon precipitation. Consistent with our result, McKenna et al. (2020) found a cold SST bias over the northwestern Indian Ocean in the CMIP6 multi-model mean. Fathrio et al. (2017) showed that the SST cold bias over the western Indian Ocean in the CMIP5 multi-model mean has a seasonal cycle with the coldest SST bias occurring in April, whereas the coldest SST bias in our CMIP6 multi-model mean occurs in May. GISS-E2-1-G and GISS-E2-1-H fail to simulate a realistic second minimum SST in August (Fig. 7b), which would lead to overly intense tropical cyclones. SST in the northwestern Indian Ocean determines the onset of the summer monsoon (Sijikumar and Rajeev, 2012; Jiang and Li, 2011). The primary maximum SST is two months later in ACCESS-ESM1-5 than in WOA18 (Fig. 7b), which suggests a delayed summer monsoon onset in projections using that model. 
https://doi.org/10.5194/os-2021-102

Preprint. Discussion started: 27 October 2021

\subsection{Impact of model characteristics on SST seasonal extrema}

We have shown that biases in $T_{\max }, T_{\min }$ and $T_{c y c l e}$ are different between models. We now use the diversity in the 20 CMIP6 models to explore the effects of different model characteristics on the magnitude of these biases as quantified by global areaweighted RMSE for $T_{\max }, T_{\min }, T_{c y c l e}$ and $T_{\text {mean }}$.

No significant correlation was found between the modelsâ ${ }^{\mathrm{TM}}$ seasonal biases and horizontal ocean resolution (supplementary

210 Fig. S3). Chassignet et al. (2020) used four pairs of matched low-resolution and high-resolution ocean simulations from FSUHYCOM, AWI-FESOM, NCAR-POP and IAP-LICOM to isolate the effect of ocean horizontal resolution, and compared their representation of global SST. They found that enhanced horizontal resolution does not deliver unambiguous SST bias improvement in all regions for all models, which is consistent with our finding. Nor did we find any correlation of seasonal biases with atmospheric resolution (supplementary Fig. S5), ocean grid type, ocean vertical coordinate, and inclusion (or not) of biogeochemical processes (circles or squares in Figs. 8 and 9).

The only characteristic yielding a statistically significant relationship was the ocean vertical resolution (Figs. 8, 9). The importance of vertical resolution for reducing seasonal biases is not unexpected: SST is influenced by ocean stratification and ocean vertical mixing processes, whose representation depends upon the vertical resolution. It has been found that high resolution in the upper ocean is important for the representation of diurnal and intraseasonal SST variability in ocean general circulation models (Misra et al., 2008; Xavier et al., 2008; Ge et al., 2017). Ideally we would have considered the number of vertical levels in the upper ocean. However, the number of vertical levels in the upper ocean (e.g. upper $200 \mathrm{~m}$ ) cannot be unambiguously determined for models using an isopycnal or sigma vertical coordinate (6 out of 20 in our study) as their level depths vary with location and time (Bleck, 2002; Shchepetkin and McWilliams, 2005). Excluding the isopycnal and sigma models, the remaining high vertical resolution models are mainly from the Met Office Hadley Centre family, and hence any relationship between SST biases and vertical resolution in the upper ocean might have been overly influenced by that particular family. Hence we use the total number of vertical levels and top grid cell thickness (table 1) as proxies for the vertical resolution. Our study emphasises the importance of vertical resolution for simulating seasonal extreme SST and annual mean SST.

For the 20 models, there is a decrease in bias with increasing total number of vertical levels (Fig. 8). We calculated the intermodel correlation between global RMSE and total number of vertical levels following the method of Wang et al. (2014). The correlations are significant for $T_{\max }, T_{\min }$, and $T_{\text {mean }}$, with the largest correlation of -0.648 for $T_{\max }$. The higher correlation between global $T_{\max }$ RMSE and ocean vertical resolution is likely linked to shallower mixed layer depths in summer than in winter. RMSE is also correlated with top grid thickness (but with smaller correlation than total number of vertical levels): models with a smaller top grid thickness tend to have smaller biases (Fig. 9).

The impact of ocean vertical resolution on SST biases varies with latitude and season. Ocean vertical resolution is most important for $T_{\max }$ at low latitudes (supplementary Figs. S1-2). SST biases decrease with number of vertical levels in the Benguela, Humboldt and California upwelling regions (supplementary Figs. S6-8). Only the Canary upwelling region, which has the smallest SST bias among the main four eastern boundary upwelling regions, does not have a good inter-model correlation between SST biases and ocean vertical resolution (supplementary Fig. S9). 

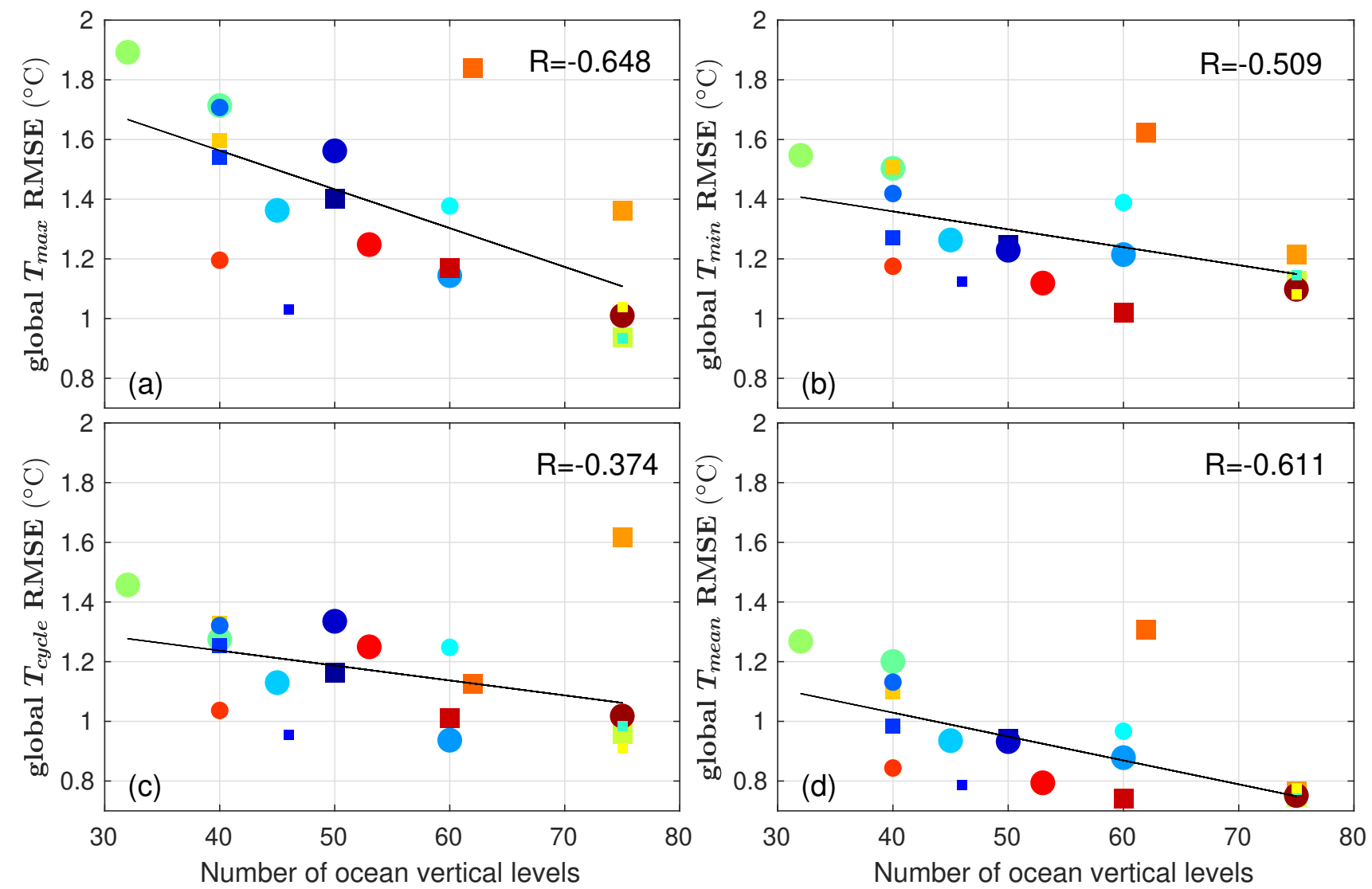

\begin{tabular}{|llllllll|}
\hline- & ACCESS-CM2 & $\bullet$ & BCC-ESM1 & GFDL-CM4 & HadGEM3-GC31-MM & $\bullet$ MPI-ESM1-2-HR \\
- & ACCESS-ESM1-5 & $\bullet$ & CESM2 & GISS-E2-1-G & INM-CM5-0 & $\bullet$ & NorESM2-MM \\
- & AWI-CM-1-1-MR & $\bullet$ & CanESM5 & GISS-E2-1-H & IPSL-CM6A-LR & SAM0-UNICON \\
BCC-CSM2-MR & 0 & E3SM-1-0 & HadGEM3-GC31-LL & MIROC6 & UKESM1-0-LL \\
\hline
\end{tabular}

Figure 8. Global RMSE of (a) $T_{\max }$, (b) $T_{\text {min }}$, (c) $T_{c y c l e}$ and (d) $T_{\text {mean }}$, all against the total number of vertical levels in ocean. Circles represent earth system models, while squares represent non earth system models. The size of the markers represents the ocean horizontal resolution for that model, with larger markers for models with lower horizontal resolution. The black line is the line of best fit (with the least sum of squared errors). The inter-model correlation $\mathrm{R}$ is shown on each panel. 
https://doi.org/10.5194/os-2021-102

Preprint. Discussion started: 27 October 2021

(c) Author(s) 2021. CC BY 4.0 License.
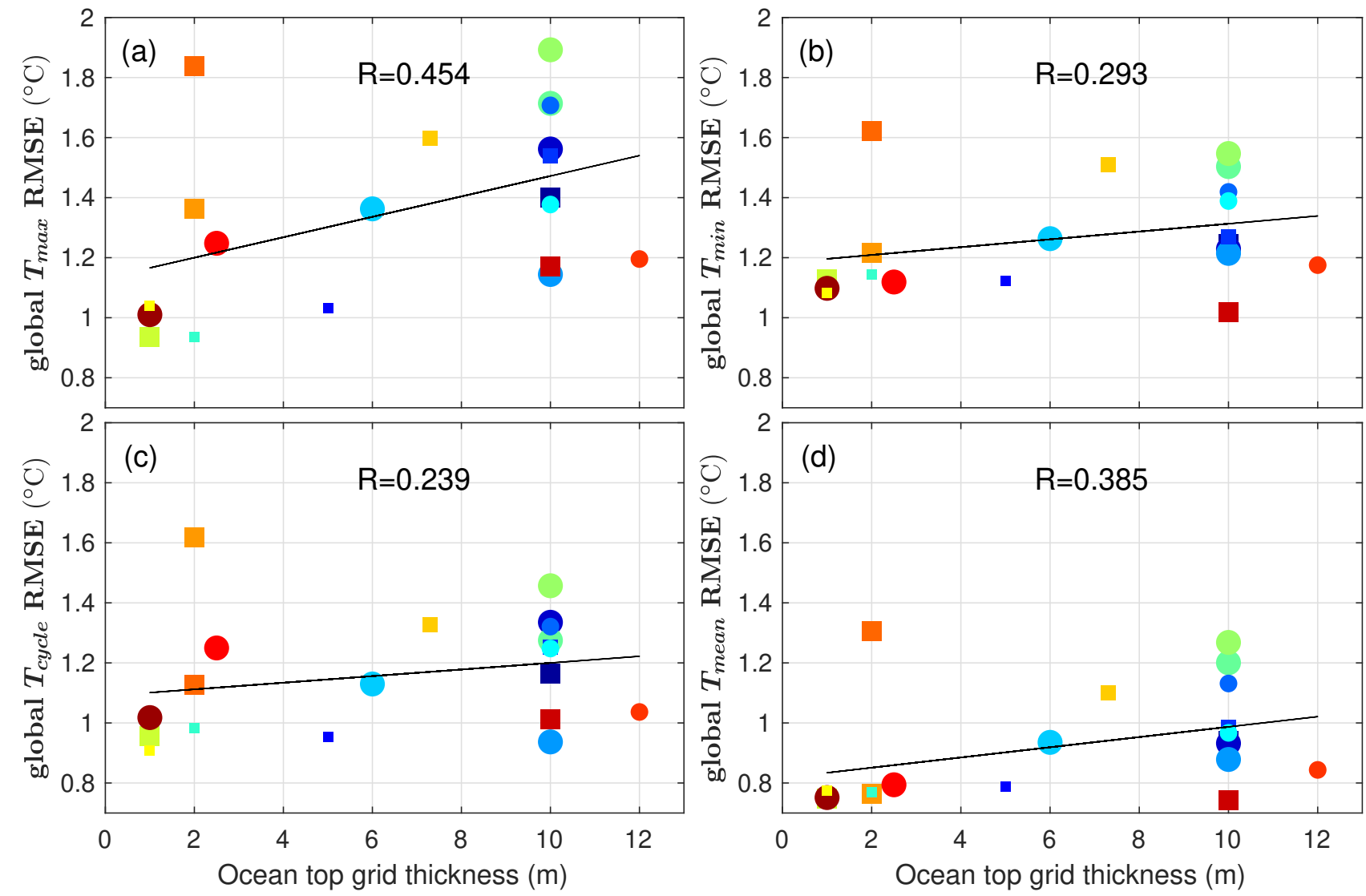

\begin{tabular}{|llllllll|}
\hline- & ACCESS-CM2 & $\bullet$ & BCC-ESM1 & GFDL-CM4 & HadGEM3-GC31-MM & $\bullet$ MPI-ESM1-2-HR \\
- ACCESS-ESM1-5 & $\bullet$ & CESM2 & GISS-E2-1-G & INM-CM5-0 & $\bullet$ & NorESM2-MM \\
- & AWI-CM-1-1-MR & 0 & CanESM5 & GISS-E2-1-H & IPSL-CM6A-LR & SAM0-UNICON \\
BCC-CSM2-MR & 0 & E3SM-1-0 & HadGEM3-GC31-LL & MIROC6 & UKESM1-0-LL \\
\hline
\end{tabular}

Figure 9. As in Fig. 8, but against the thickness of top grid in ocean.

\section{Conclusions}

Using the newly-released CMIP6 models, this study provides a global view of the biases in SST extrema, identifies regions with large seasonal bias, and suggests a future direction to reduce these biases. Global area-weighted $T_{\max }, T_{\min }$ and $T_{\text {cycle }}$ RMSEs are typically $1-2^{\circ} \mathrm{C}$. Most models have $T_{\max }$ and $T_{\min }$ biases of the same sign at most locations, apart from IPSLCM6A-LR and E3SM-1-0 which have an overall warm bias in $T_{\max }$ and an overall cold bias in $T_{\min }$. When averaged across the whole globe, the bias in $T_{\text {mean }}$ is typically consistent with $T_{\max }$ and $T_{\min }$ biases, but certain regions (eastern boundary upwelling regions, polar regions, the eastern equatorial Atlantic, the North Pacific) show significant differences between winter and summer biases. Seasonal processes related to wind and cloud could be the main reasons for seasonal SST biases, but depend upon region. Further investigations of wind and cloud biases in CMIP6 models for different seasons could be undertaken to 
https://doi.org/10.5194/os-2021-102

Preprint. Discussion started: 27 October 2021

(c) Author(s) 2021. CC BY 4.0 License.

(c) (1)

better understand the causes of seasonal SST biases. In regions with non-sinusoidal SST seasonal cycles, models tend to have biases in amplitudes and/or phases of their SST seasonal cycles. For the models we examined, those with increased vertical resolution in the ocean generally had a better representation of SST extrema, particularly $T_{\max }$. This is likely related to the ability of the higher resolution models to better represent the surface mixed layer, and particularly shallow mixed layers in summer. For improving the accuracy of future climate projections, we suggest that as much priority (or possibly more) should be given to increasing vertical ocean model resolution as is given to increasing horizontal resolution.

Code availability. All codes that support the finding of this study are available from YW, upon reasonable request.

Author contributions. YW performed data analysis and prepared the manuscript under the supervision of KJH, DPS and GMD.

Competing interests. The authors declare that they have no conflict of interest.

Acknowledgements. We thank NOAA (National Oceanic and Atmospheric Administration), University of Hamburg and Met Office Hadley Centre for allowing access to the climatology data sets. We thank all modelling centres for carrying out CMIP6 simulations used here, and Earth System Grid Federation (ESGF) for archiving the data and providing access. This work was supported by the European Research 260 Council under the European Union's Horizon 2020 research and innovation programme (grant agreement $\mathrm{n}^{\circ} 741120$ ). YW was supported by the China Scholarship Council (grant agreement $n^{\circ}$ 201706310146). Computing and data storage resources were provided by JASMIN, the UK collaborative data analysis facility. 
https://doi.org/10.5194/os-2021-102

Preprint. Discussion started: 27 October 2021

\section{References}

Andrews, M. B., Ridley, J. K., Wood, R. A., Andrews, T., Blockley, E. W., Booth, B., Burke, E., Dittus, A. J., Florek, P., and Gray,

L. J.: Historical simulations with HadGEM3-GC3. 1 for CMIP6, Journal of Advances in Modeling Earth Systems, p. e2019MS001995, https://doi.org/10.1029/2019MS001995, 2020.

Bayr, T., Latif, M., Dommenget, D., Wengel, C., Harlaß, J., and Park, W.: Mean-state dependence of ENSO atmospheric feedbacks in climate models, Climate Dynamics, 50, 3171-3194, https://doi.org/10.1007/s00382-017-3799-2, 2018.

Bayr, T., Domeisen, D. I., and Wengel, C.: The effect of the equatorial Pacific cold SST bias on simulated ENSO teleconnections to the North Pacific and California, Climate Dynamics, 53, 3771-3789, https://doi.org/10.1007/s00382-019-04746-9, 2019.

Beadling, R., Russell, J., Stouffer, R., Mazloff, M., Talley, L., Goodman, P., Sallée, J., Hewitt, H., Hyder, P., and Pandde, A.: Representation of Southern Ocean Properties across Coupled Model Intercomparison Project Generations: CMIP3 to CMIP6, Journal of Climate, 33, 6555-6581, https://doi.org/10.1175/JCLI-D-19-0970.1, 2020.

Beaumet, J., Krinner, G., Déqué, M., Haarsma, R., and Li, L.: Assessing bias corrections of oceanic surface conditions for atmospheric models, Geoscientific Model Development, 12, 321-342, https://doi.org/https://dx.doi.org/10.5194/gmd-12-321-2019, 2019.

Bi, D., Dix, M., Marsland, S., O’Farrell, S., Sullivan, A., Bodman, R., Law, R., Harman, I., Srbinovsky, J., Rashid, H. A., et al.: Configuration and spin-up of ACCESS-CM2, the new generation Australian Community Climate and Earth System Simulator Coupled Model, Journal of Southern Hemisphere Earth Systems Science, 70, 225-251, https://doi.org/10.1071/ES19040, 2020.

Bleck, R.: An oceanic general circulation model framed in hybrid isopycnic-Cartesian coordinates, Ocean Modelling, 4, 55-88, https://doi.org/10.1016/S1463-5003(01)00012-9, 2002.

Boucher, O., Servonnat, J., Albright, A. L., Aumont, O., Balkanski, Y., Bastrikov, V., Bekki, S., Bonnet, R., Bony, S., and Bopp, L.: Presentation and evaluation of the IPSL-CM6A-LR climate model, Journal of Advances in Modeling Earth Systems, pp. e2019MS002 010-in, https://doi.org/10.1029/2019ms002010, 2020.

Burls, N. J., Muir, L., Vincent, E. M., and Fedorov, A.: Extra-tropical origin of equatorial Pacific cold bias in climate models with links to cloud albedo, Climate Dynamics, 49, 2093-2113, https://doi.org/10.1007/s00382-016-3435-6, 2017.

Chassignet, E., Yeager, S., Fox-Kemper, B., Bozec, A., Castruccio, F., Danabasoglu, G., Kim, W., Koldunov, N., Li, Y., Lin, P., Liu, H., Sein, D., Sidorenko, D., Wang, Q., and Xu, X.: Impact of horizontal resolution on global ocean-sea-ice model simulations based on the experimental protocols of the Ocean Model Intercomparison Project phase 2 (OMIP-2), Geoscientific Model Development, 13, 45954637, https://doi.org/10.5194/gmd-2019-374, 2020.

Cheung, W. W. and Frölicher, T. L.: Marine heatwaves exacerbate climate change impacts for fisheries in the northeast Pacific, Scientific Reports, 10, 1-10, https://doi.org/10.1038/s41598-020-63650-z, 2020.

Danabasoglu, G., Lamarque, J.-F., Bacmeister, J., Bailey, D., DuVivier, A., Edwards, J., Emmons, L., Fasullo, J., Garcia, R., and Gettelman, A.: The Community Earth System Model version 2 (CESM2), Journal of Advances in Modeling Earth Systems, 12, e2019MS001 916, https://doi.org/10.1029/2019MS001916, 2020.

Dare, R. A. and McBride, J. L.: The threshold sea surface temperature condition for tropical cyclogenesis, Journal of Climate, 24, 4570-4576, https://doi.org/10.1175/JCLI-D-10-05006.1, 2011.

Fathrio, I., Iizuka, S., Manda, A., Kodama, Y.-M., Ishida, S., Moteki, Q., Yamada, H., and Tachibana, Y.: Assessment of western Indian Ocean SST bias of CMIP5 models, Journal of Geophysical Research: Oceans, 122, 3123-3140, https://doi.org/10.1002/2016JC012443, 2017. 
https://doi.org/10.5194/os-2021-102

Preprint. Discussion started: 27 October 2021 P., Guilyardi, E., Jakob, C., Kattsov, V., Reason, C., and Rummukainen, M.: Evaluation of Climate Models, Climate Change 2013: The Physical Science Basis. Contribution of Working Group I to the Fifth Assessment Report of the Intergovernmental Panel on Climate Change, pp. 741-866, https://doi.org/10.1017/CBO9781107415324, 2013.

Frölicher, T. L. and Laufkötter, C.: Emerging risks from marine heat waves, Nature Communications, 9, 1-4, https://doi.org/10.1038/s41467018-03163-6, 2018.

Ge, X., Wang, W., Kumar, A., and Zhang, Y.: Importance of the vertical resolution in simulating SST diurnal and intraseasonal variability in an oceanic general circulation model, Journal of Climate, 30, 3963-3978, https://doi.org/10.1175/JCLI-D-16-0689.1, 2017.

Gilford, D. M., Solomon, S., and Emanuel, K. A.: On the seasonal cycles of tropical cyclone potential intensity, Journal of Climate, 30, 6085-6096, https://doi.org/10.1175/JCLI-D-16-0827.1, 2017.

Golaz, J.-C., Caldwell, P. M., Van Roekel, L. P., Petersen, M. R., Tang, Q., Wolfe, J. D., Abeshu, G., Anantharaj, V., Asay-Davis, X. S., and Bader, D. C.: The DOE E3SM coupled model version 1: Overview and evaluation at standard resolution, Journal of Advances in Modeling Earth Systems, 11, 2089-2129, https://doi.org/10.1029/2018MS001603, 2019.

Gouretski, V.: World Ocean Circulation Experiment-Argo global hydrographic climatology, Ocean Science, 14, 1127-1146, https://doi.org/10.5194/os-14-1127-2018, 2018.

Greeves, C., Pope, V., Stratton, R., and Martin, G.: Representation of Northern Hemisphere winter storm tracks in climate models, Climate Dynamics, 28, 683-702, https://doi.org/10.1007/s00382-006-0205-x, 2007.

Held, I., Guo, H., Adcroft, A., Dunne, J., Horowitz, L., Krasting, J., Shevliakova, E., Winton, M., Zhao, M., and Bushuk, M.: Structure and performance of GFDL's CM4. 0 climate model, Journal of Advances in Modeling Earth Systems, 11, 3691-3727, https://doi.org/10.1029/2019MS001829, 2019

Holland, G. J.: The maximum potential intensity of tropical cyclones, Journal of the Atmospheric Sciences, 54, 2519-2541,

Hughes, T. P., Anderson, K. D., Connolly, S. R., Heron, S. F., Kerry, J. T., Lough, J. M., Baird, A. H., Baum, J. K., Berumen, M. L., Bridge, T. C., et al.: Spatial and temporal patterns of mass bleaching of corals in the Anthropocene, Science, 359, 80-83, https://doi.org/10.1126/science.aan8048, 2018.

Hyder, P., Edwards, J. M., Allan, R. P., Hewitt, H. T., Bracegirdle, T. J., Gregory, J. M., Wood, R. A., Meijers, A. J., Mulcahy, J., and Field, P.: Critical Southern Ocean climate model biases traced to atmospheric model cloud errors, Nature Communications, 9, 1-17, https://doi.org/10.1038/s41467-018-05634-2, 2018.

Jiang, X. and Li, J.: Influence of the annual cycle of sea surface temperature on the monsoon onset, Journal of Geophysical Research: Atmospheres, 116, https://doi.org/10.1029/2010JD015236, 2011

Jones, T., Parrish, J. K., Peterson, W. T., Bjorkstedt, E. P., Bond, N. A., Ballance, L. T., Bowes, V., Hipfner, J. M., Burgess, H. K., Dolliver, J. E., et al.: Massive mortality of a planktivorous seabird in response to a marine heatwave, Geophysical Research Letters, 45, 3193-3202, https://doi.org/10.1002/2017GL076164, 2018.

Kelley, M., Schmidt, G. A., Nazarenko, L. S., Bauer, S. E., Ruedy, R., Russell, G. L., Ackerman, A. S., Aleinov, I., Bauer, M., and Bleck, R.: GISS-E2. 1: Configurations and Climatology, Journal of Advances in Modeling Earth Systems, p. e2019MS002025, https://doi.org/10.1029/2019MS002025, 2020.

Law, R. M., Ziehn, T., Matear, R. J., Lenton, A., Chamberlain, M. A., Stevens, L. E., Ying-Ping, W., Srbinovsky, J., Bi, D., and Yan, H.: The carbon cycle in the Australian Community Climate and Earth System Simulator (ACCESS-ESM1)-Part 1: Model description and pre-industrial simulation, Geoscientific Model Development, 10, 2567, https://doi.org/10.5194/gmd-10-2567-2017, 2017. 
https://doi.org/10.5194/os-2021-102

Preprint. Discussion started: 27 October 2021

Letelier, J., Pizarro, O., and Nuñez, S.: Seasonal variability of coastal upwelling and the upwelling front off central Chile, Journal of Geophysical Research: Oceans, 114, https://doi.org/10.1029/2008JC005171, 2009.

Levine, R. C. and Turner, A. G.: Dependence of Indian monsoon rainfall on moisture fluxes across the Arabian Sea and the impact of coupled model sea surface temperature biases, Climate Dynamics, 38, 2167-2190, https://doi.org/10.1007/s00382-011-1096-z, 2012.

Li, G. and Xie, S.-P.: Origins of tropical-wide SST biases in CMIP multi-model ensembles, Geophysical Research Letters, 39, https://doi.org/10.1029/2012g1053777, 2012.

Li, J.-L., Xu, K.-M., Jiang, J., Lee, W.-L., Wang, L.-C., Yu, J.-Y., Stephens, G., Fetzer, E., and Wang, Y.-H.: An overview of CMIP5 and CMIP6 simulated cloud ice, radiation fields, surface wind stress, sea surface temperatures, and precipitation over tropical and subtropical oceans, Journal of Geophysical Research: Atmospheres, 125, e2020JD032 848, https://doi.org/10.1029/2020JD032848, 2020.

Liu, F., Lu, J., Luo, Y., Huang, Y., and Song, F.: On the oceanic origin for the enhanced seasonal cycle of SST in the midlatitudes under global warming, Journal of Climate, 33, 8401-8413, https://doi.org/10.1175/JCLI-D-20-0114.1, 2020.

Locarnini, R. A., Mishonov, A. V., Baranova, O. K., Boyer, T. P., Zweng, M. M., Garcia, H. E., Reagan, J. R., Seidov, D., Weathers, K., Paver, C. R., and Smolyar, I.: World Ocean Atlas 2018, Volume 1: Temperature, 2018.

Lyu, K., Zhang, X., and Church, J. A.: Regional dynamic sea level simulated in the CMIP5 and CMIP6 models: mean biases, future projections, and their linkages, Journal of Climate, 33, 6377-6398, https://doi.org/10.1175/JCLI-D-19-1029.1, 2020.

McKenna, S., Santoso, A., Gupta, A. S., Taschetto, A. S., and Cai, W.: Indian Ocean Dipole in CMIP5 and CMIP6: characteristics, biases, and links to ENSO, Scientific Reports, 10, 1-13, https://doi.org/10.1038/s41598-020-68268-9, 2020.

Misra, V., Marx, L., Brunke, M., and Zeng, X.: The equatorial Pacific cold tongue bias in a coupled climate model, Journal of Climate, 21, 5852-5869, https://doi.org/10.1175/2008JCLI2205.1, 2008.

Müller, W. A., Jungclaus, J. H., Mauritsen, T., Baehr, J., Bittner, M., Budich, R., Bunzel, F., Esch, M., Ghosh, R., and Haak, H.: A Higherresolution Version of the Max Planck Institute Earth System Model (MPI-ESM1. 2-HR), Journal of Advances in Modeling Earth Systems, 10, 1383-1413, https://doi.org/10.1029/2017MS001217, 2018.

Palmen, E.: On the formation and structure of tropical hurricanes, Geophysica, 3, 26-38, 1948.

Park, S., Shin, J., Kim, S., Oh, E., and Kim, Y.: Global climate simulated by the Seoul National University atmosphere model version 0 with a unified convection scheme (SAM0-UNICON), Journal of Climate, 32, 2917-2949, https://doi.org/10.1175/JCLI-D-18-0796.1, 2019.

Prodhomme, C., Terray, P., Masson, S., Izumo, T., Tozuka, T., and Yamagata, T.: Impacts of Indian Ocean SST biases on the Indian Monsoon: as simulated in a global coupled model, Climate Dynamics, 42, 271-290, https://doi.org/10.1007/s00382-013-1671-6, 2014.

Prodhomme, C., Voldoire, A., Exarchou, E., Deppenmeier, A.-L., García-Serrano, J., and Guemas, V.: How does the seasonal cycle control equatorial Atlantic interannual variability?, Geophysical Research Letters, 46, 916-922, https://doi.org/10.1029/2018GL080837, 2019.

Rayner, N., Parker, D. E., Horton, E., Folland, C. K., Alexander, L. V., Rowell, D., Kent, E., and Kaplan, A.: Global analyses of sea surface temperature, sea ice, and night marine air temperature since the late nineteenth century, Journal of Geophysical Research: Atmospheres, 108, https://doi.org/10.1029/2002jd002670, 2003.

Richter, I.: Climate model biases in the eastern tropical oceans: causes, impacts and ways forward, Wiley Interdisciplinary Reviews: Climate Change, 6, 345-358, https://doi.org/10.1002/wcc.338, 2015 .

Richter, I. and Tokinaga, H.: An overview of the performance of CMIP6 models in the tropical Atlantic: mean state, variability, and remote impacts, Climate Dynamics, 55, 2579-2601, https://doi.org/10.1007/s00382-020-05409-w, 2020.

Richter, I., Xie, S.-P., Wittenberg, A. T., and Masumoto, Y.: Tropical Atlantic biases and their relation to surface wind stress and terrestrial precipitation, Climate Dynamics, 38, 985-1001, https://doi.org/10.1007/s00382-011-1038-9, 2012. 
https://doi.org/10.5194/os-2021-102

Preprint. Discussion started: 27 October 2021

Richter, I., Xie, S.-P., Behera, S. K., Doi, T., and Masumoto, Y.: Equatorial Atlantic variability and its relation to mean state biases in CMIP5, Climate Dynamics, 42, 171-188, https://doi.org/10.1007/s00382-012-1624-5, 2014.

Rouault, M., Florenchie, P., Fauchereau, N., and Reason, C. J.: South East tropical Atlantic warm events and southern African rainfall, Geophysical Research Letters, 30, https://doi.org/10.1029/2002GL014840, 2003.

Roxy, M.: Sensitivity of precipitation to sea surface temperature over the tropical summer monsoon region-and its quantification, Climate Dynamics, 43, 1159-1169, https://doi.org/10.1007/s00382-013-1881-y, 2014.

Seland, Ø., Bentsen, M., Olivié, D., Toniazzo, T., Gjermundsen, A., Graff, L. S., Debernard, J. B., Gupta, A. K., He, Y.-C., Kirkevåg, A., et al.: Overview of the Norwegian Earth System Model (NorESM2) and key climate response of CMIP6 DECK, historical, and scenario simulations, Geoscientific Model Development, 13, 6165-6200, 2020.

Sellar, A. A., Jones, C. G., Mulcahy, J. P., Tang, Y., Yool, A., Wiltshire, A., O’Connor, F. M., Stringer, M., Hill, R., and Palmieri, J.: UKESM1: Description and evaluation of the UK Earth System Model, Journal of Advances in Modeling Earth Systems, 11, 4513-4558, https://doi.org/10.1029/2019MS001739, 2019.

Semmler, T., Danilov, S., Gierz, P., Goessling, H., Hegewald, J., Hinrichs, C., Koldunov, N. V., Khosravi, N., Mu, L., and Rackow, T.: Simulations for CMIP6 with the AWI climate model AWI-CM-1-1, Journal of Advances in Modeling Earth Systems, 12, e2019MS002 009, https://doi.org/10.1029/2019MS002009, 2020.

Shchepetkin, A. F. and McWilliams, J. C.: The regional oceanic modeling system (ROMS): a split-explicit, free-surface, topographyfollowing-coordinate oceanic model, Ocean Modelling, 9, 347-404, https://doi.org/10.1016/j.ocemod.2004.08.002, 2005.

Shu, Q., Wang, Q., Song, Z., Qiao, F., Zhao, J., Chu, M., and Li, X.: Assessment of sea ice extent in CMIP6 with comparison to observations and CMIP5, Geophysical Research Letters, 47, e2020GL087 965, https://doi.org/10.1029/2020GL087965, 2020.

Sijikumar, S. and Rajeev, K.: Role of the Arabian Sea warm pool on the precipitation characteristics during the monsoon onset period, Journal of Climate, 25, 1890-1899, https://doi.org/10.1175/JCLI-D-11-00286.1, 2012.

Song, F. and Zhang, G. J.: The impacts of horizontal resolution on the seasonally dependent biases of the Northeastern Pacific ITCZ in coupled climate models, Journal of Climate, 33, 941-957, https://doi.org/10.1175/JCLI-D-19-0399.1, 2020.

Sun, Y., Zhong, Z., Li, T., Yi, L., Hu, Y., Wan, H., Chen, H., Liao, Q., Ma, C., and Li, Q.: Impact of ocean warming on tropical cyclone size and its destructiveness, Scientific Reports, 7, 1-10, https://doi.org/10.1038/s41598-017-08533-6, 2017.

Swart, N. C., Cole, J. N., Kharin, V. V., Lazare, M., Scinocca, J. F., Gillett, N. P., Anstey, J., Arora, V., Christian, J. R., and Hanna, S.: The Canadian Earth System Model version 5 (CanESM5. 0.3), Geoscientific Model Development, 12, 4823-4873, https://doi.org/10.5194/gmd-12-4823-2019, 2019.

Talley, L. D.: Some aspects of ocean heat transport by the shallow, intermediate and deep overturning circulations, Geophysical MonographAmerican Geophysical Union, 112, 1-22, 1999.

Tatebe, H., Ogura, T., Nitta, T., Komuro, Y., Ogochi, K., Takemura, T., Sudo, K., Sekiguchi, M., Abe, M., and Saito, F.: Description and basic evaluation of simulated mean state, internal variability, and climate sensitivity in MIROC6, Geoscientific Model Development, 12 , 2727-2765, https://doi.org/10.5194/gmd-12-2727-2019, 2019.

Trenberth, K. E.: What are the seasons?, Bulletin of the American Meteorological Society, 64, 1276-1282, https://doi.org/10.1175/15200477(1983)064<1276:WATS>2.0.CO;2, 1983.

Volodin, E., Mortikov, E., Kostrykin, S., Galin, V. Y., Lykossov, V., Gritsun, A., Diansky, N., Gusev, A., and Iakovlev, N.: Simulation of the present-day climate with the climate model INMCM5, Climate Dynamics, 49, 3715-3734, https://doi.org/10.1007/s00382-017-3539-7, 2017. 
https://doi.org/10.5194/os-2021-102

Preprint. Discussion started: 27 October 2021

(c) Author(s) 2021. CC BY 4.0 License.

(c) (1)

Wang, C., Zhang, L., Lee, S.-K., Wu, L., and Mechoso, C. R.: A global perspective on CMIP5 climate model biases, Nature Climate Change, 4, 201-205, https://doi.org/10.1038/nclimate2118, 2014.

Wang, C., Zou, L., and Zhou, T.: SST biases over the Northwest Pacific and possible causes in CMIP5 models, Science China Earth Sciences, 61, 792-803, https://doi.org/10.1007/s11430-017-9171-8, 2018.

Wu, T., Lu, Y., Fang, Y., Xin, X., Li, L., Li, W., Jie, W., Zhang, J., Liu, Y., and Zhang, L.: The Beijing Climate Center climate system model (BCC-CSM): The main progress from CMIP5 to CMIP6, Geoscientific Model Development, 12, 1573-1600, https://doi.org/10.5194/gmd12-1573-2019, 2019.

Wu, T., Zhang, F., Zhang, J., Jie, W., Zhang, Y., Wu, F., Li, L., Yan, J., Liu, X., Lu, X., et al.: Beijing Climate Center Earth System Model version 1 (BCC-ESM1): model description and evaluation of aerosol simulations., Geoscientific Model Development, 13, https://doi.org/10.5194/gmd-13-977-2020, 2020.

Xavier, P. K., Duvel, J.-P., and Doblas-Reyes, F. J.: Boreal summer intraseasonal variability in coupled seasonal hindcasts, Journal of Climate, 21, 4477-4497, https://doi.org/10.1175/2008JCLI2216.1, 2008.

Yashayaev, I. M. and Zveryaev, I. I.: Climate of the seasonal cycle in the North Pacific and the North Atlantic oceans, International Journal of Climatology: A Journal of the Royal Meteorological Society, 21, 401-417, https://doi.org/10.1002/joc.585, 2001.

Yu, L.: Global variations in oceanic evaporation (1958-2005): The role of the changing wind speed, Journal of Climate, 20, 5376-5390, https://doi.org/10.1175/2007JCLI1714.1, 2007.

Zhang, L. and Zhao, C.: Processes and mechanisms for the model SST biases in the North Atlantic and North Pacific: a link with the Atlantic meridional overturning circulation, Journal of Advances in Modeling Earth Systems, 7, 739-758, https://doi.org/10.1002/2014MS000415, 2015.

Zhu, Y., Zhang, R.-H., and Sun, J.: North Pacific upper-ocean cold temperature biases in CMIP6 simulations and the role of regional vertical mixing, Journal of Climate, 33, 7523-7538, https://doi.org/10.1175/jcli-d-19-0654.1, 2020. 